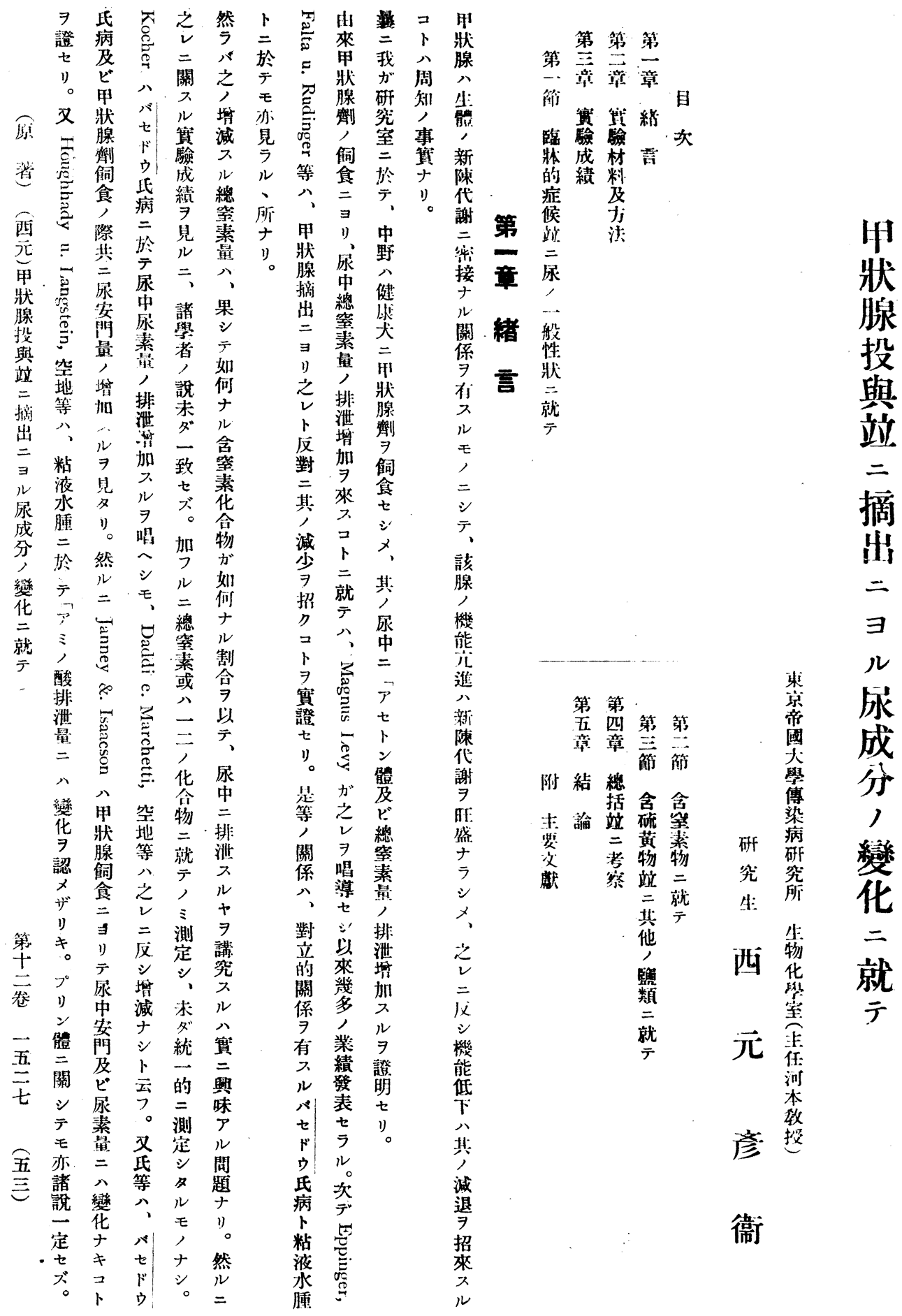




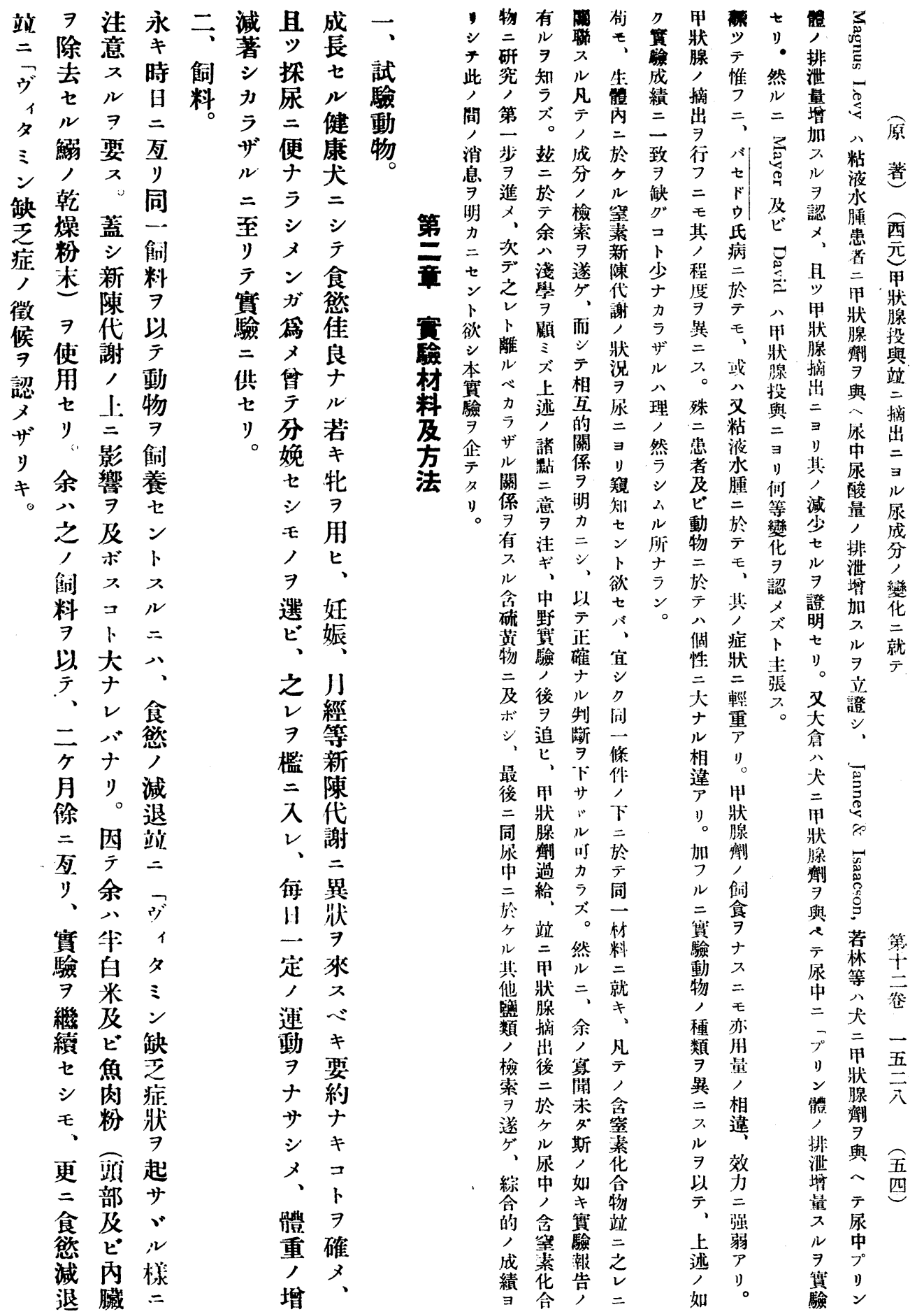




\section{第一表 食慨表 (一)}

\begin{tabular}{|c|c|c|c|c|c|}
\hline & 瓦 & 蛋白筫(總䇪素) & $\begin{array}{l}\text { 念水 } \\
\text { 炭素 }\end{array}$ & 脂脏 & $\begin{array}{ll}\text { 力 } & \text { 口 } \\
\text { 1) } & - \\
\end{array}$ \\
\hline 牛白米 & 250.0 & $17.175(2.750)$ & 191.25 & 3.75 & 887.5 \\
\hline 魚肉粉 & 31.0 & $21.327(3.413)$ & ～ & 0.81 & 97.7 \\
\hline & & $38.502(6.163)$ & 191.25 & 4.56 & 985.2 \\
\hline
\end{tabular}

食 飭 表 (二)

\begin{tabular}{|c|c|c|c|c|c|}
\hline & 瓦 & 蛋白質(總營素) & 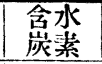 & 脂脏 & \begin{tabular}{ll|} 
力 & 口 \\
1 & - \\
\end{tabular} \\
\hline 牛白米 & 250.0 & $17.175(2.750)$ & 191.25 & 3.75 & 887.5 \\
\hline $\begin{array}{l}\text { 甲狀腺 } \\
\text { 眇川 }\end{array}$ & 10.07 & $7.625(1.220)$ & I & 1 & 31.9 \\
\hline \multirow[t]{2}{*}{ 魚肉粉 } & 20.3 & $13.990(2.232)$ & I & 0.53 & 60.9 \\
\hline & & $38.915(6.212)$ & 191.25 & 4.28 & 980.3 \\
\hline
\end{tabular}

畀

化

$$
\text { 皒 }
$$

粉時ク腸甲广飽化每五卜

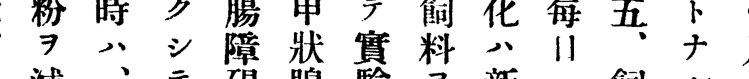

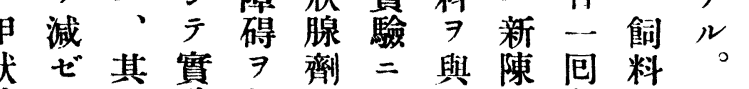
腺, 驗起八供公代午投 劑第中二入體七方謝後興 第二適コ重り充 $=-\cdots$ 表含賞卜每。分影暗 食有ナナナ楫方皦頃

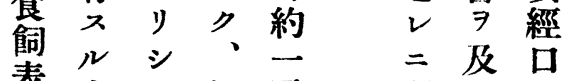

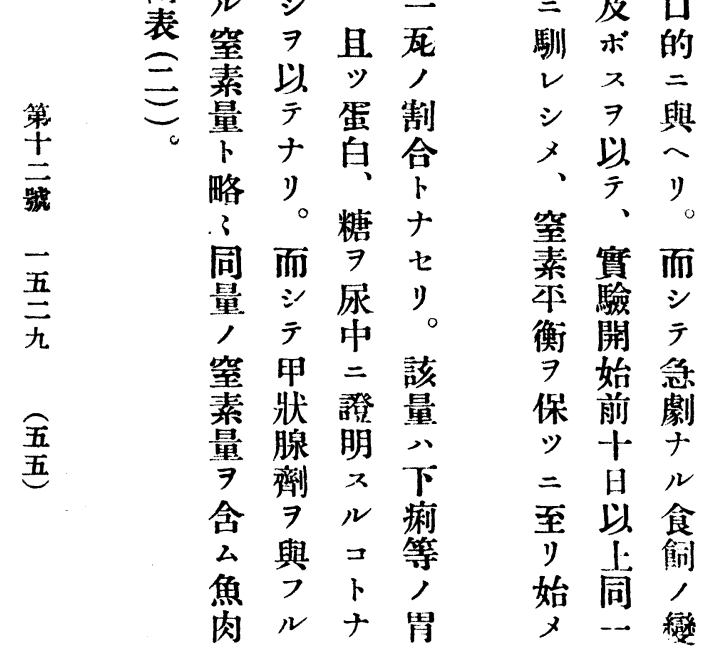

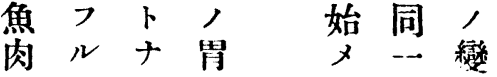

魚余矢四学尘三

粉 2 蛋餜和米調

中 $\exists$ 皇 料七一理

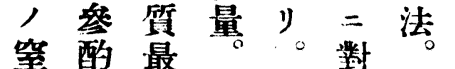

素七尔第 兰

牙过食制

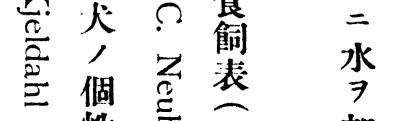

氏性、总三 加

法叒

り等

各 $\begin{aligned} & \text { 品 } \\ & 3\end{aligned}$

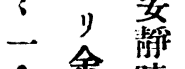

- 余 時

$\%$ 用 於

及於

ビ シ 其

- 金,

食 中

一虫命

\% 召有

马算

食泉次

有算等

掼素

㬝之量

重之

讦寻每

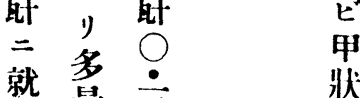

₹量㝠腺

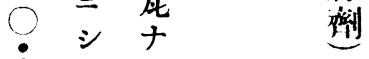

六于少及

三作記占

死白載

, 米

割 及”

合 ビ。
飭
焚
キ
之
乙

魚

肉

粉

裂

期

$\exists$

$=$

魚

肉

粉

及

卢

状

制

定

'

水 


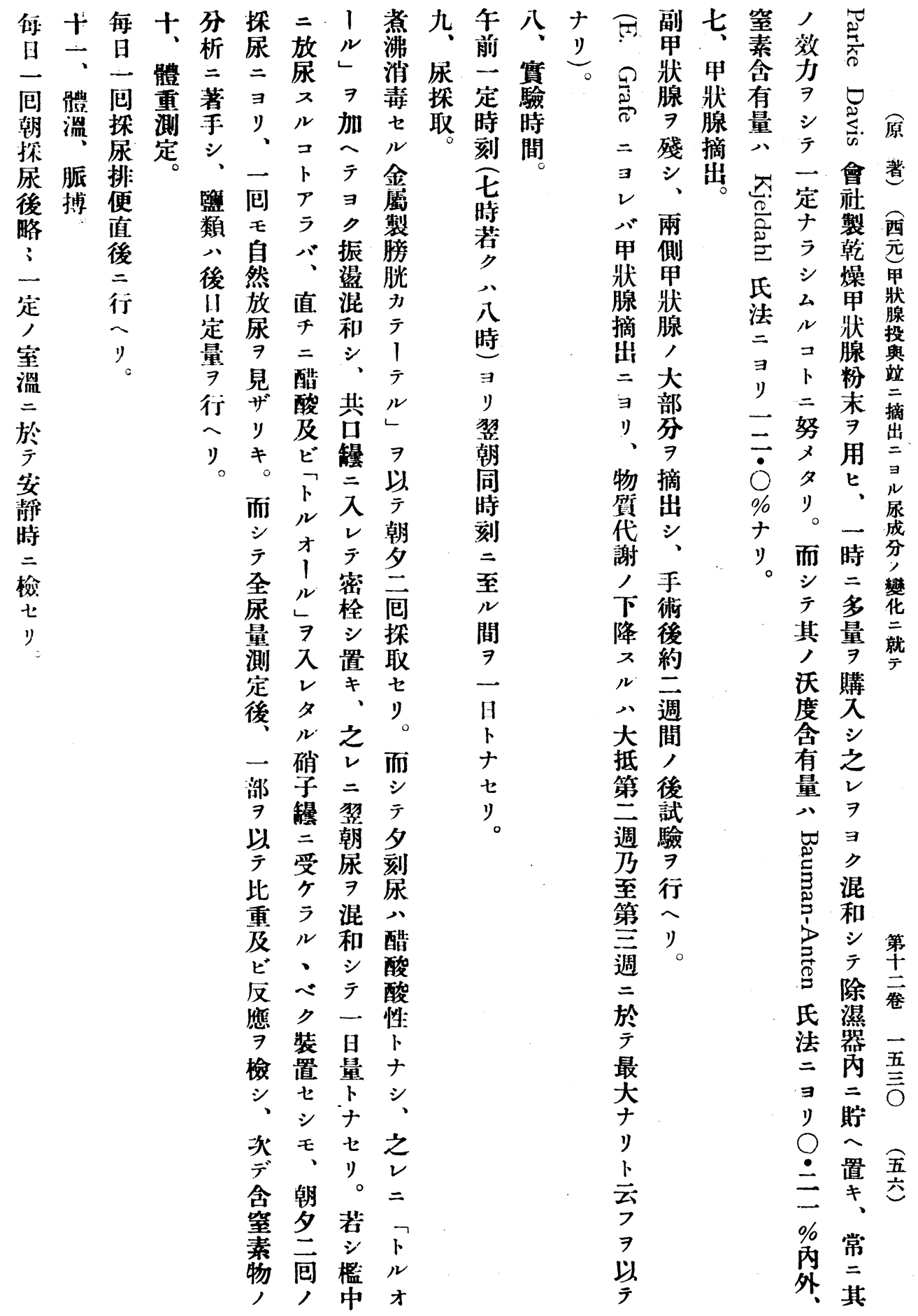




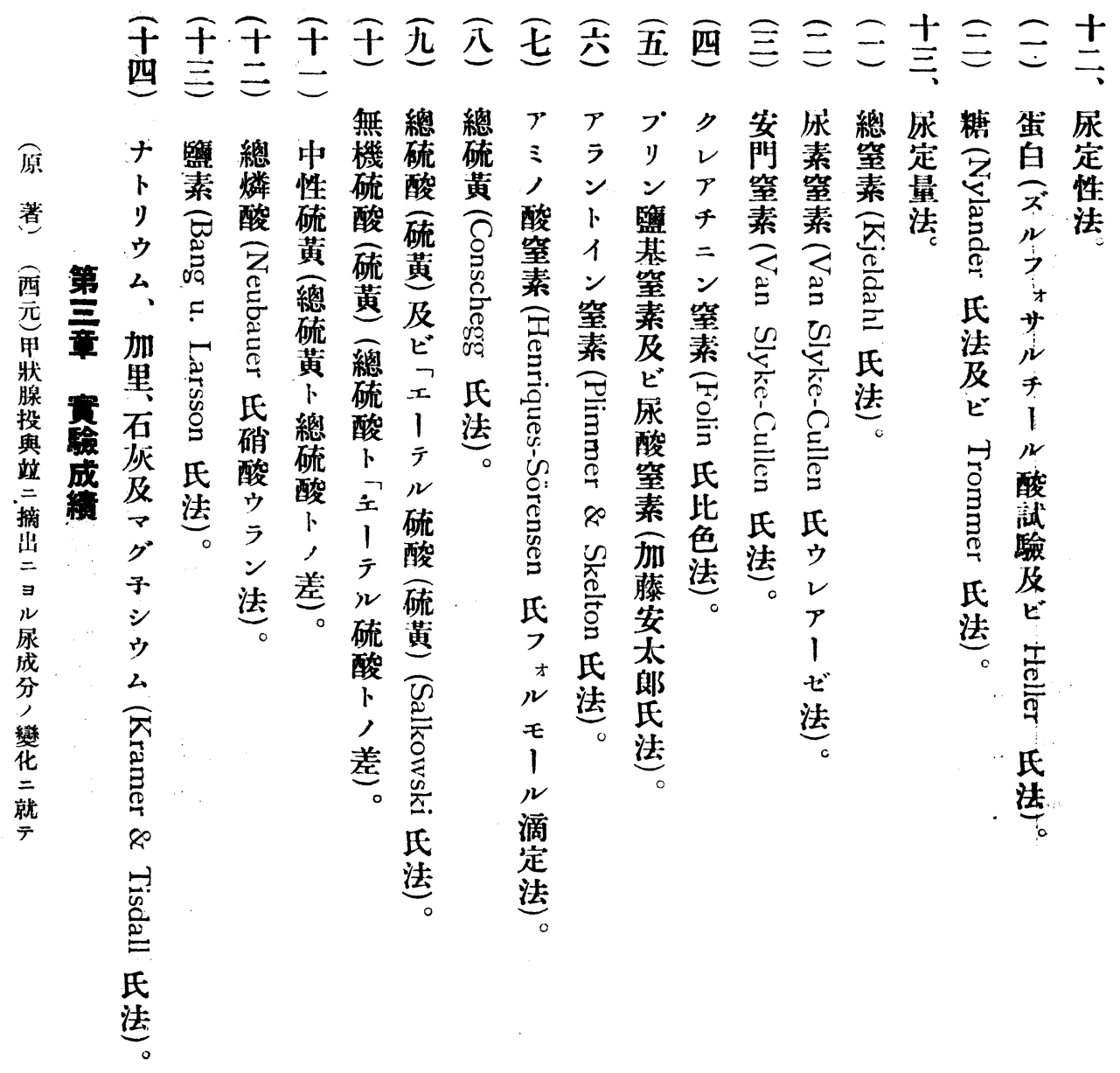

第
春
吾
三
全
七 
第

\begin{tabular}{|c|c|c|c|c|c|c|}
\hline $\begin{array}{l}\text { 锂尿 } \\
\text { (理) }\end{array}$ & 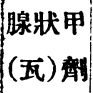 & 搏脈 & $\begin{array}{c}\text { 溫 䯠 } \\
\text { (C) }\end{array}$ & $\begin{array}{c}\text { 重 體 } \\
\text { （硅） }\end{array}$ & 附日 & 騟試 \\
\hline 593 & & 80 & 38.2 & 10.042 & 1 & \multirow{4}{*}{$\begin{array}{l}\text { 前 } \\
\text { 期 }\end{array}$} \\
\hline 566 & & 83 & 38.2 & 10.047 & 2 & \\
\hline 555 & & 82 & 38.2 & 10.050 & 3 & \\
\hline 571 & & 82 & 38.2 & 10.046 & 均本 & \\
\hline 708 & 10.07 & 83 & 38.2 & 10.055 & 4 & \multirow{7}{*}{$\begin{array}{l}\text { 試 } \\
\text { 驗 }\end{array}$} \\
\hline 652 & " & 93 & 38.4 & 9.968 & 5 & \\
\hline 535 & " & 106 & 38.6 & 9.768 & 6 & \\
\hline 524 & ". & 112 & 38.7 & 9.705 & 7 & \\
\hline 599 & ". & 114 & 38.7 & 9.672 & 8 & \\
\hline 625 & ", & 116 & 38.8 & 9.587 & 9 & \\
\hline 574 & ". & 116 & 38.8 & 9.492 & 10 & \\
\hline 494 & & 118 & 38.6 & 9.4 .5 & 11 & \multirow{4}{*}{ 後 } \\
\hline 540 & & 108 & 38.7 & 9.515 & 12 & \\
\hline 498 & & 99 & 38.4 & 9.635 & 12 & \\
\hline 582 & & 83 & 38.2 & 9.708 & 14 & \\
\hline 458 & & 68 & 37.7 & 10.373 & 15 & \multirow{5}{*}{$\begin{array}{l}\text { 試 } \\
\text { 驗 } \\
\text { 期 } \\
\cong \\
\cong\end{array}$} \\
\hline 445 & & 71 & 38.0 & 10.357 & 16 & \\
\hline 425 & & 72 & 38.0 & 10.370 & 17 & \\
\hline 443 & & 72 & 38.0 & 10.360 & 18 & \\
\hline 443 & & 71 & 37.9 & 10.365 & 均不 & \\
\hline
\end{tabular}

キ余療尔三至余

其合合气v

志不鉒占以

概 頭 ルョナ後上

要 $尹$ 經 數, 原

马 犬 待過 、昌筫

述 = チ

こ就、甲狀試材

ンキ再狀腺驗料

同七腺劑 $尹$ 及元

一前劑投行 七゙

實述, 興七方萠

驗七影

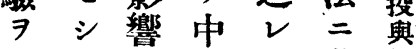

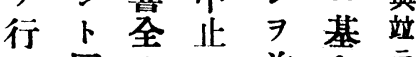

七同名

- - 消 $儿$ 期實出

其條失後占驗=

, 件七尿+ $\Rightarrow$ 利

三人

實下 7 , 比成

驗二認譇次之分

成數メ成 デと榃

綪日夕分每 7 花

, 間儿略 日四

本試後 3 飼期就

均驗、前 料二

值 $\Rightarrow$ 甲期二分

马行狀, 甲 $\%$

求 $\mathrm{E}$ 腺狀狀

メ之ヨ態腺 師

、午摘二劑 天

以 $\exists$ 出復 $\rightarrow$ 一

試 兵歸加定

本 驗'

寞期十 2 飼

驗三数迄投料

人

成卜 $\exists$ 後

精ナ經期、会

卜七 5 - 尿一

ナり體ナ週中吾

也。另七間, 豆

》恢り繼空

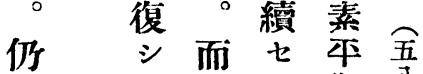

三沓言衡贫

之 且 $\overline{7}$

v 爾試保

二 創後驗

就面 - 期 = 


\begin{tabular}{|c|c|c|c|c|c|c|c|c|c|c|c|c|}
\hline & & & & & & $=$ & & & & & & \\
\hline 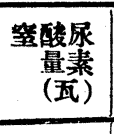 & 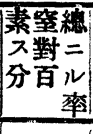 & 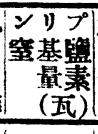 & 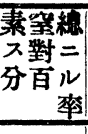 & $\begin{array}{l}\text { ミア } \\
\text { 素窒酸 } \\
\text { (五) 量 }\end{array}$ & 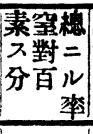 & \begin{tabular}{|c|} 
整門安 \\
量意 \\
$($ 五)
\end{tabular} & 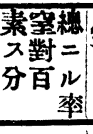 & 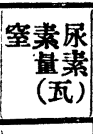 & 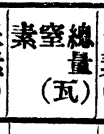 & 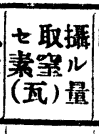 & 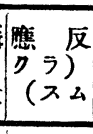 & (溫宣) \\
\hline $0.02 s 1$ & 0.17 & 0.0063 & 0.63 & 0.0216 & 7.2 & 0.250 & 77.5 & 2.706 & 3.489 & 6.168 & 性酸翏 & 1011.3 \\
\hline 0.0260 & 0.14 & 0.0054 & 0.75 & 0.0274 & 6.9 & 0.256 & 77.5 & 2.860 & s.687 & ", & 性性 & 1011.3 \\
\hline 0.0231 & 0.16 & 0.0062 & 0.72 & 0.0255 & 6.5 & 0.233 & 78.4 & 2.807 & 3.578 & ", & 卜访多 & 1012.3 \\
\hline 0.0241 & 0.16 & 0.0060 & 0.70 & 0.0248 & 6.9 & .0 .246 & 77.8 & 2.791 & 2.584 & " & $\begin{array}{l}\text { アル尿 } \\
\text { リカ }\end{array}$ & 1011.6 \\
\hline 0.0312 & 0.17 & 0.0063 & 0.95 & 0.0335 & 6.4 & 0.251 & 77.6 & 3.038 & 3.911 & 6.209 & & 1011.3 \\
\hline 0.0416 & 0.16 & 0.0088 & 0.95 & 0.0505 & 5.6 & 0.295 & 79.1 & 4.147 & \begin{tabular}{l|l}
5.239 \\
\end{tabular} & , & & 1013.5 \\
\hline 0.0388 & 0.18 & 0.0082 & 0.94 & 0.0433 & 6.3 & 0.288 & 77.5 & 3.557 & 4.589 & , & & 1014.3 \\
\hline 0.0442 & 0.18 & 0.0091 & 1.18 & 0.0603 & 7.4 & 0.375 & 75.2 & 3.794 & $\begin{array}{l}1.040 \\
\end{array}$ & , & & 1015.7 \\
\hline 0.0460 & 0.20 & 0.0103 & 0.99 & 0.0519 & 5.7 & 0.295 & 77.4 & 4.08 & 5.211 & " & & $101+.3$ \\
\hline 0.0531 & 0.20 & 0.0111 & 1.22 & 0.0687 & 6.0 & 0.240 & 77.0 & 4.333 & 3.628 & ," & & 1013.7 \\
\hline 0.0584 & 0.22 & 0.0126 & 1.04 & 0.0600 & 5.8 & 0.343 & 77.3 & 4.569 & 5.972 & ", & & 1015.3 \\
\hline 0.0404 & 0.20 & 0.0095 & 1.08 & 0.0511 & 6.4 & 0.311 & 76.5 & 3.700 & 4.833 & 6.163 & & $|1015.5|$ \\
\hline 0.0357 & 0.18 & 0.0081 & 0.95 & 0.0445 & 6.3 & 0.289 & 77.6 & 3.560 & 4.585 & , & & 1013.7 \\
\hline 0.0312 & 0.13 & 0.0054 & 0.71 & 0.0272 & 7.0 & 0.307 & 72.1 & 3.157 & 4.384 & , & & 1014.2 \\
\hline 0.0252 & 0.13 & 0.0044 & 0.59 & 0.0199 & 7.8 & 0.263 & 76.2 & 2.559 & 3.358 & , & & 1010.5 \\
\hline 0.0166 & 0.11 & 0.0029 & 0.73 & 0.0215 & 8.5 & 0.243 & 76.1 & 2.169 & 2.848 & 6.163 & & 1011.7 \\
\hline 0.0171 & 0.12 & 0.0033 & 0.54 & 0.0150 & 7.6 & 0.210 & 80.3 & 2.199 & 2.737 &, & & $1011.3^{4}$ \\
\hline 0.0173 & 0.12 & 0.0036 & 0.57 & 0.0174 & 6.7 & 0.202 & 77.9 & 2.358 & 3.012 & , & & 1012.3 \\
\hline 0.0161 & 0.13 & 0.0037 & 0.66 & 0.0194 & 8.7 & 0.245 & 78.3 & 2.201 & $\begin{array}{l}2.809 \\
\end{array}$ & , & & 1010.8 \\
\hline 0.0168 & 0.12 & 0.0034 & 0.62 & 0.0183 & 7.8 & 0.223 & 78.2 & 2.231 & 2.852 & , & & 1011.5 \\
\hline
\end{tabular}




\begin{tabular}{|c|c|c|c|c|c|c|c|c|}
\hline $\begin{array}{l}\text { 酸燐總 } \\
\text { （无）量 }\end{array}$ & 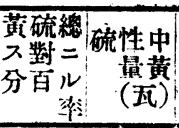 & 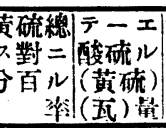 & 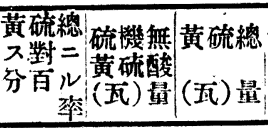 & 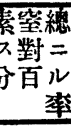 & 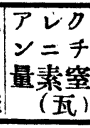 & 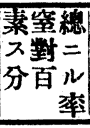 & 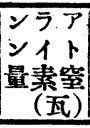 & 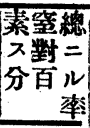 \\
\hline 0.742 & 21.10 .0873 & 8.10 .0128 & $67.9|0.11930 .1749|$ & 3.5 & 0.124 & 7.3 & 0.254 & 0.64 \\
\hline 0.765 & 19.40 .0344 & 8.60 .0151 & 75.30 .1265 .0 .1861 & 3.4 & 0.126 & 6.4 & 0.229 & 0.62 \\
\hline 0.748 & 24.30 .0474 & 6.70 .0133 & $68.90 .1: 6670.2040$ & 3.5 & 0.127 & 6.3 & 0.230 & 0.65 \\
\hline 0.752 & 21.60 .0397 & 7.80 .0187 & 70.70 .13040 .1883 & 3.5 & 0.126 & 6.7 & 0.238 & 0.64 \\
\hline 0.837 & 24.3 .0 .0559 & 6.90 .0139 & 64.90 .13570 .2047 & 3.5 & 0.134 & 7.1 & 0.267 & 0.82 \\
\hline 0.878 & 23.50 .0679 & 5.50 .0160 & 70.80 .20550 .2895 & 3.1 & 0.146 & 6.7 & 0.349 & 0.79 \\
\hline 0.767 & 25.40 .6727 & 5.40 .0152 & 69.10 .20370 .2916 & 3.2 & 0.132 & 7.6 & 0.336 & 0.84 \\
\hline 0.964 & 22.90 .0643 & 6.30 .0174 & $70.70 .1968,0.2785$ & 2.7 & 0.133 & 8.9 & 0.431 & 0.83 \\
\hline 0.926 & 27.10 .0886 & 5.00 .0154 & 69.90 .22210 .3263 & 2.5 & 0.128 & 8.7 & 0.442 & 0.90 \\
\hline 0.924 & 25.50 .0866 & 5.90 .0200 & $68.5 \mid 0.24130 .3479$ & 2.5 & 0.136 & 8.8 & 0.470 & 0.99 \\
\hline 0.901 & 20.40 .0758 & 5.70 .0214 & $73.9|0.28070 .3779|$ & 2.3 & 0.130 & $\because 9.2$ & 0.512 & 1.02 \\
\hline 0.866 & 19.10 .0600 & 5.90 .0189 & $75.5 \mid 0.24660 .3255$ & 2.6 & 0.122 & 8.8 & 0.413 & 0.83 \\
\hline 0.794 & 19.60 .0597 & 5.40 .0164 & 72.60 .21710 .3013 & 2.8 & 0.124 & 7.9 & 0.348 & 0.76 \\
\hline 0.777 & 15.20 .0531 & 6.30 .0180 & 73.10 .20750 .2850 & 3.3 & 0.128 & 7.8 & 0.315 & 0.77 \\
\hline 0.779 & 21.50 .0424 & 7.00 .0149 & $72.4^{0.15270 .2100}$ & 3.5 & 0.118 & 7.2 & 0.248 & 0.73 \\
\hline 0.640 & 18.00 .0261 & 6.60 .0102 & 69.60 .10360 .1400 & 3.9 & 0.116 & 5.7 & 0.161 & 0.59 \\
\hline 0.583 & 20.81 .0265 & 6.10 .0082 & 69.20 .09200 .1240 & 3.8 & 0.108 & 5.2 & 0.157 & 0.68 \\
\hline 0.646 & 18.10 .0266 & \begin{tabular}{l|l|l|}
5.5 & 0.0087
\end{tabular} & 70.60 .11210 .1470 & 4.0 & 0.124 & 5.6 & 0.171 & 0.61 \\
\hline 0.587 & 17.80 .0251 & \begin{tabular}{l|l|}
6.6 & 0.0102
\end{tabular} & $70.10 .1070 \mid 0.1424$ & 3.9 & 0.111 & 5.8 & 0.165 & 0.60 \\
\hline 0.614 & 18.70 .0261 & 6.20 .0093 & $69.9|0.1037| 0.1384$ & 3.9 & 0.115 & 5.6 & 0.164 & 0.62 \\
\hline
\end{tabular}




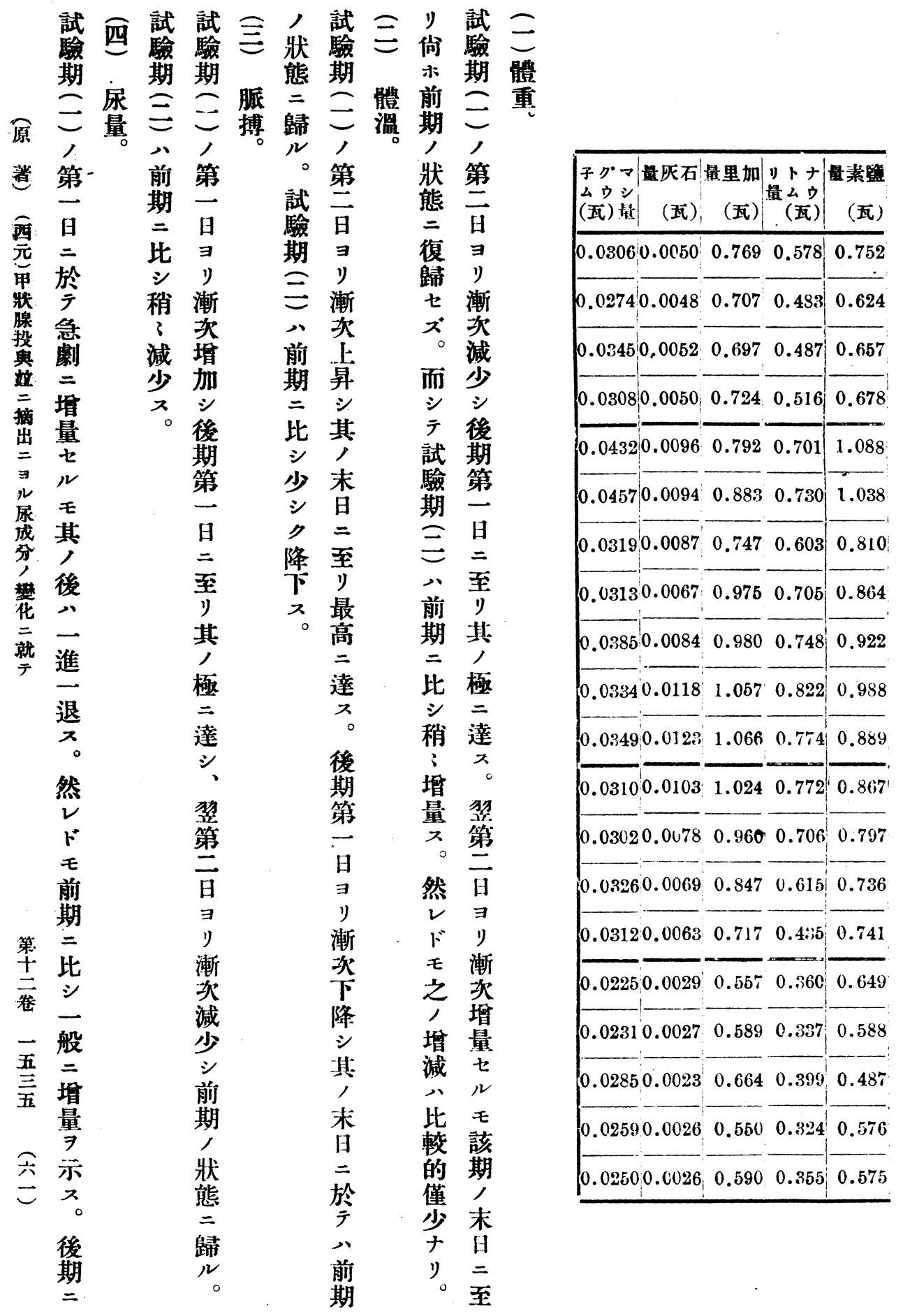


第

[育

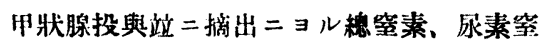

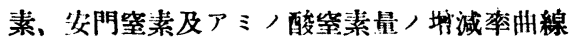

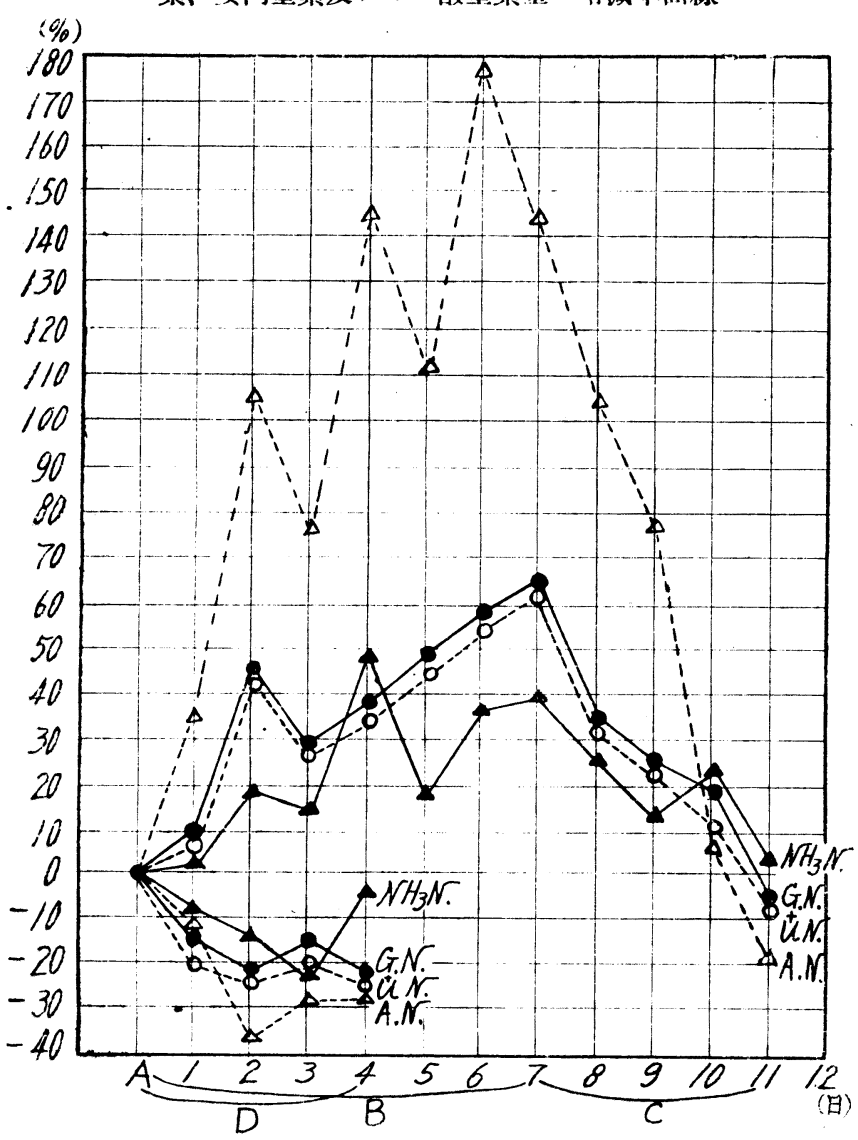

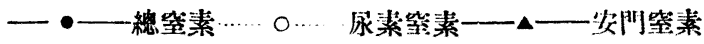

$\Delta \quad$ ア ア / 酸紫素

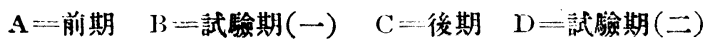

․ 漸 期二漸 期 播 完 前三

前次二於次一籁全期二

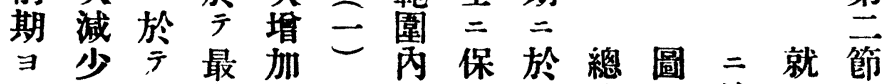

リシ 、大

モ其第卜該第 $ア レ$ 素 ビ同一全

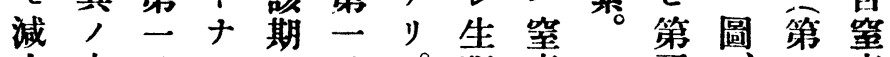

少米日ハ, 日

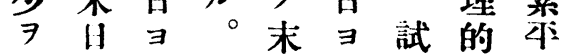

來二リ後日少驗動衡
般兵試五 於

$=$

期. 八

弱 反三比第

酸應 屋重

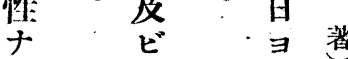

ル 後少

モ 期 隇 西

夕 少 元

刻於 $\Rightarrow$ 甲

尿 方續 牀

八 >

中增 。黄

性加試站

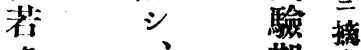

八 試 期 出

弱 襝 三

$P$ 期 $=$ 逐

於盛

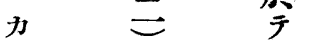

リ $=$ 八

性於前雑

期 就

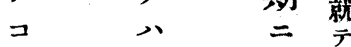

卜 前 於

期

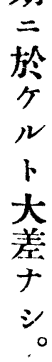

(2)

著

的

減

第

咅 


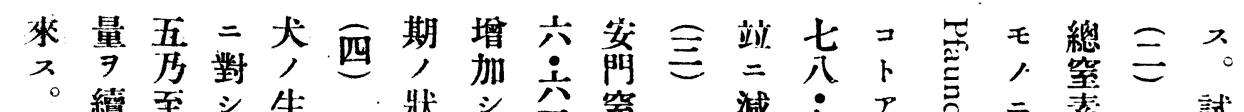

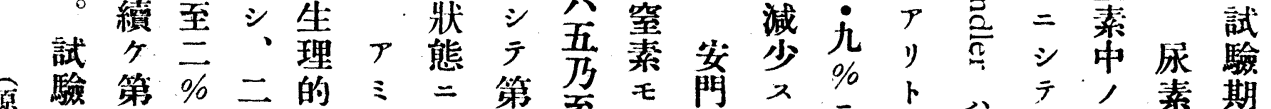

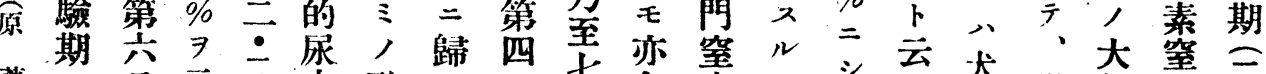

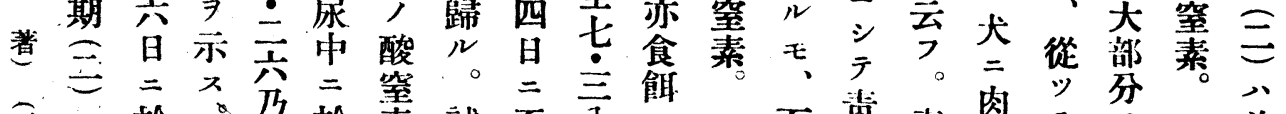

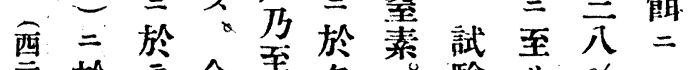
元於金畕方驗少 \% 甲 5 最人期最

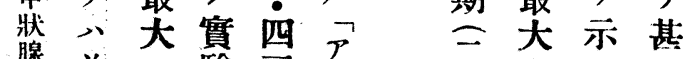

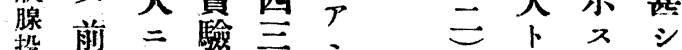

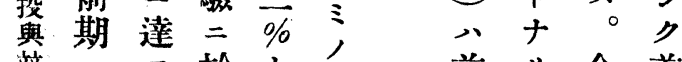

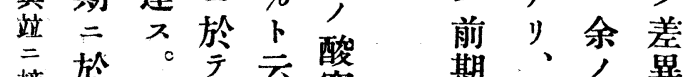

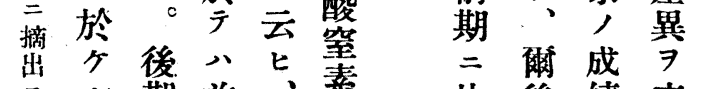

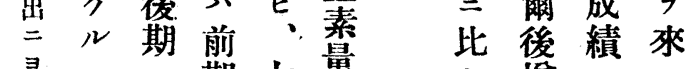

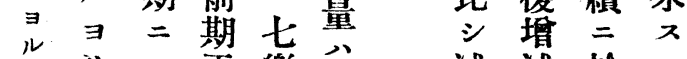

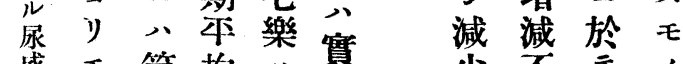

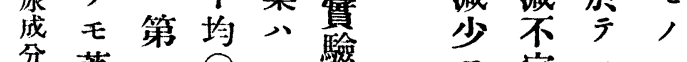

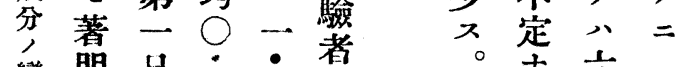

戀奛旦忘見者

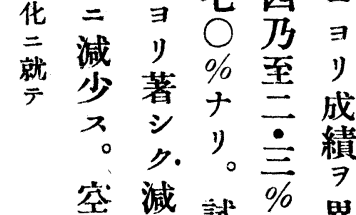

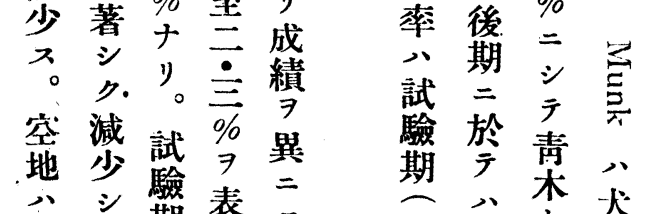

心漸期表云

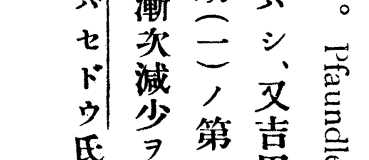

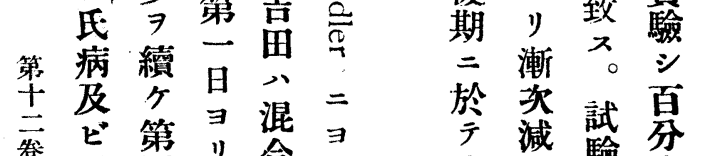

先四著食公少少驗率

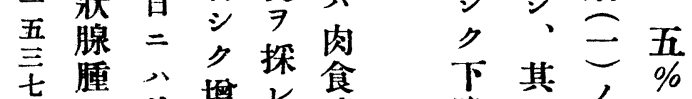

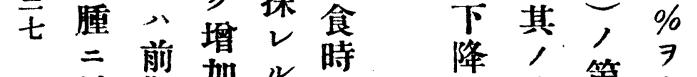

兵於期加人等第表

交亏寻学金於

正常減漸於總

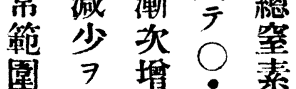

日㝵

略 ”、青

了漸 木

夏呆堢食亏分前

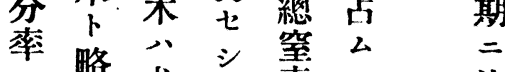

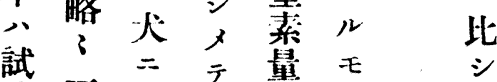

驗致类八二, 減

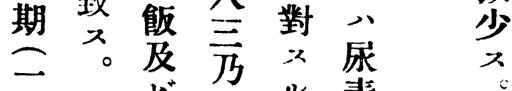

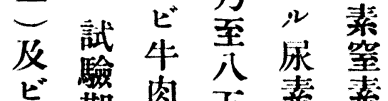

後期肉五素素

期三興 $\%$ 素》。

於、表表面而

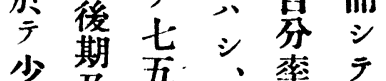

少期吾、率

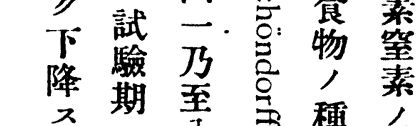

芝第略就

後当学賔

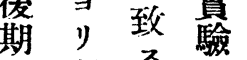

前次八

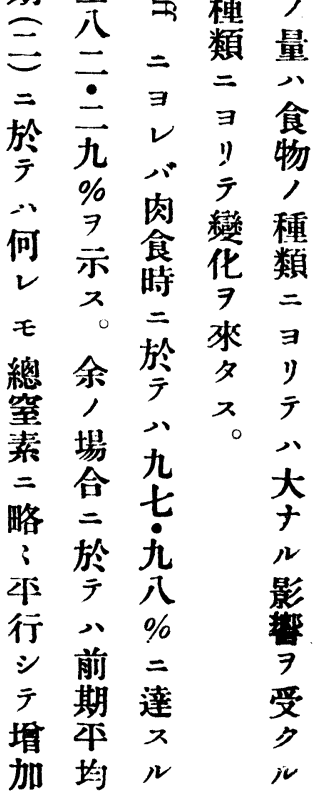


第

$$
=
$$

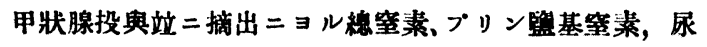

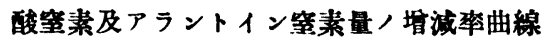
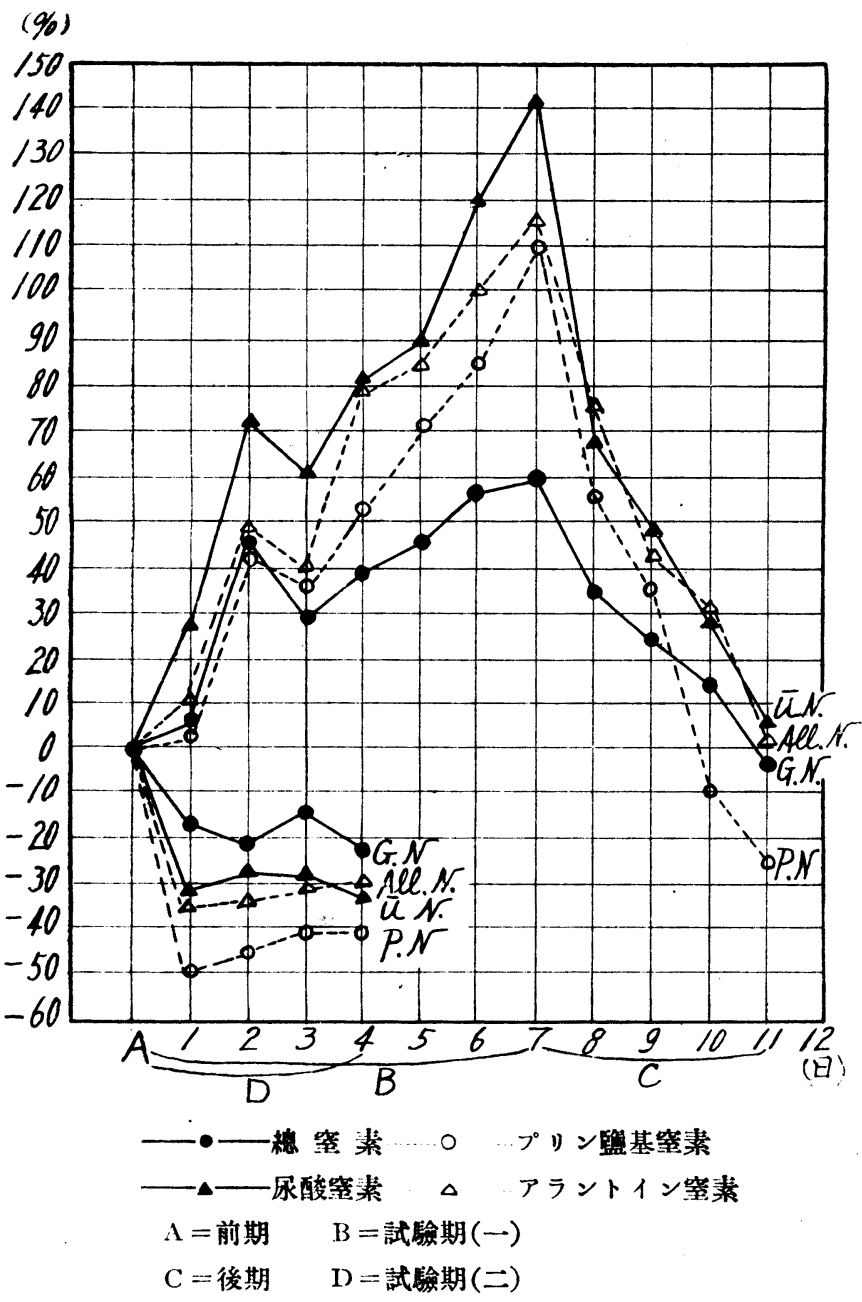

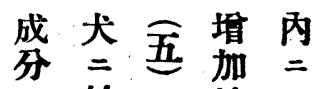

於站 $T$

ナ プ

シ、メリ減卢原

プ プ監共 云著

リ基 二 、

ンン蓕著罗西

監體素明 喿 元

及 終

㲾 良

酸 物

僅尿

少 酸

ナ

ル

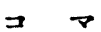

卜 $\overline{7}$

ハズ

多

數 テ

學 ᄀ

者

,

認

厶 1

所

所 迄

り 分

試

殮 而

期

二

ㄱ

第 ラ

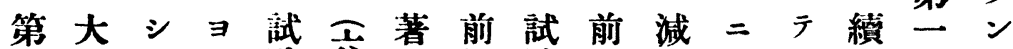

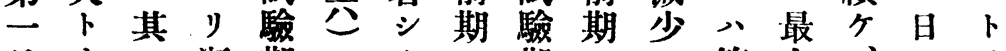

日十, 漸期

$\exists ル$ 末次三尿減於气 其

り。著こ酸少ケ三七, 日十兵漸に

漸後二シ人窒

次期於”第素。ヨ於少日早。旦坦其

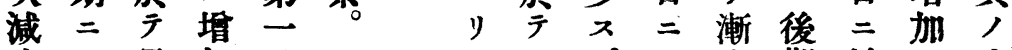

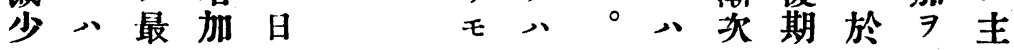

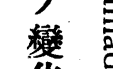

戀

隶

來 丝 y

狀

腺

興

点
$\Rightarrow$

蛋.

等 衤

八成

粘 分

液

水炛

腫就

二

於

$\bar{\Sigma}$

常

時

思

異

亏

天

去

然 -

吾

余

實畜

$=$

於 


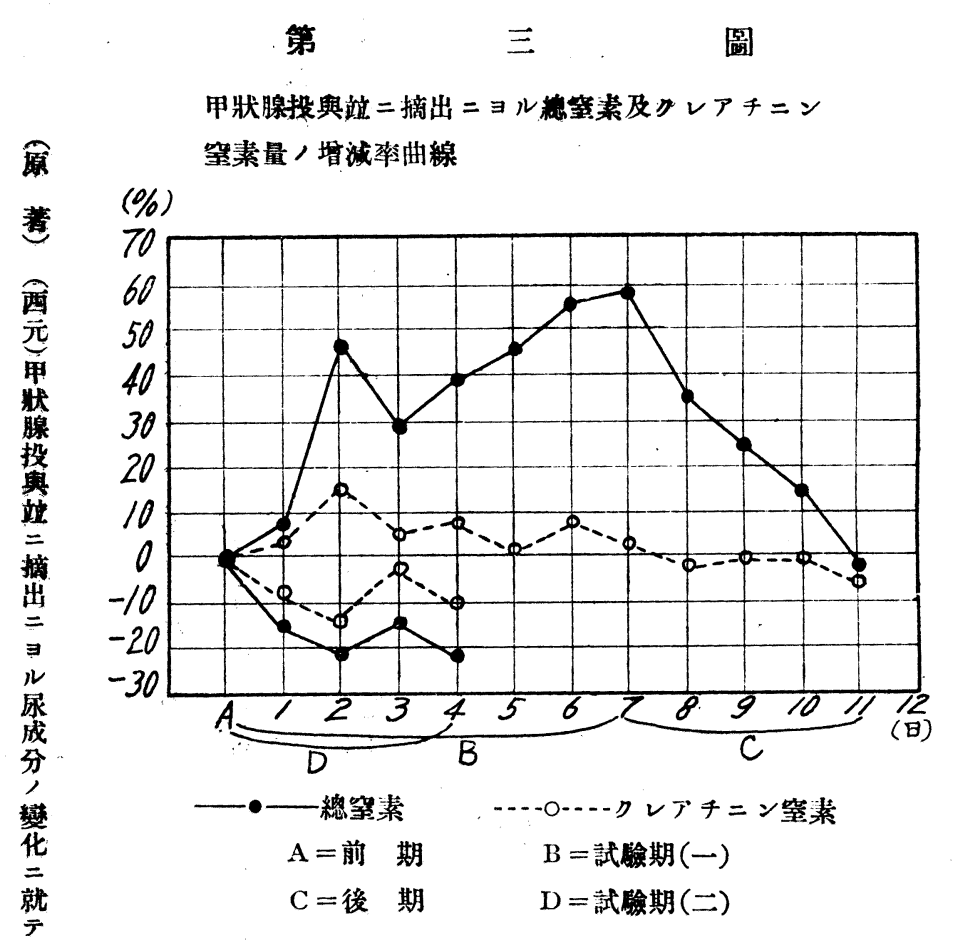

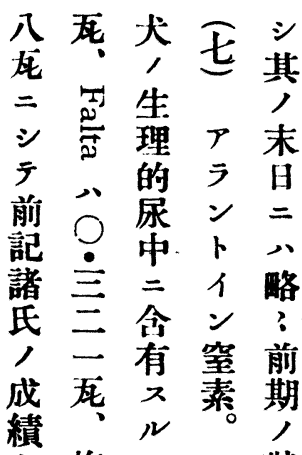

梅 ᄀ . 狀

略男艼態

¿ $\begin{array}{ll}0 & 5\end{array}$

致 $\div$ N

ス。兵 イ 敬

試龙窒就

驗七素期

期樂量 三

二 食 =

第兰慨於

加分 = 率。吅值 $\bigcirc \bigcirc$ 尿元減態第

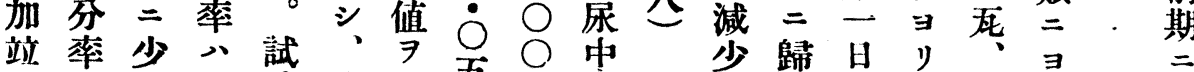

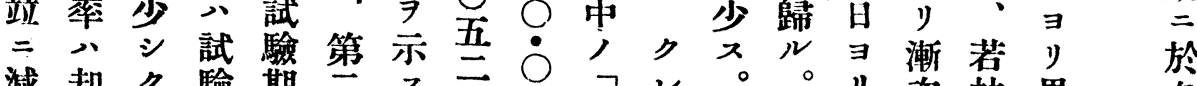

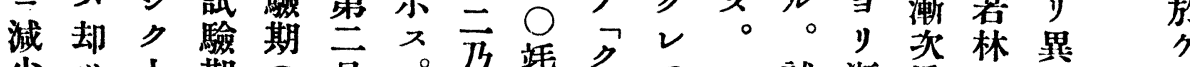

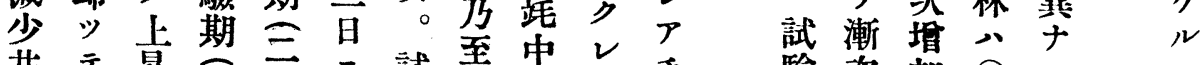

共年三三三陚至虫

第少 $、$ 試於期最三亲

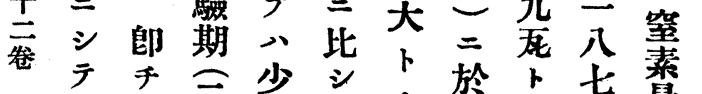

一總っ三少少ナ於云屍量

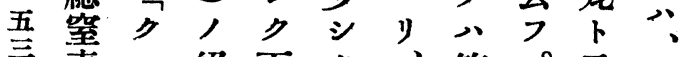

芚素 絶下第。云的

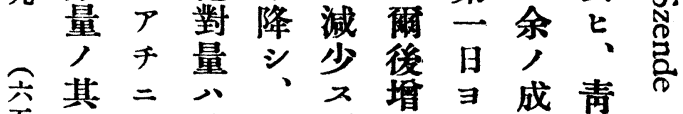

吾 $v ン$ 減後。減り績木

二窒少期 然著 少モ $モ \exists$

件素 $x=2$ 省亦 $一 v$

八量ルハ上カク近日心

ザ六反百亏坦似量一

三少、亲脗著

三亲其論 シ

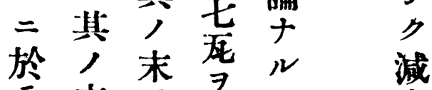

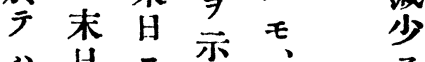

前 $=$ 示於不

期於前余前

ケ略占成

ル

著期後六

著狀期三全 
第

四

圆

甲狀腺投與站二摘出 $=ョ$ ル總硫黄、無機硫酸 (硫黄)。

エーテル硫酸(硫黄)及ビ中性硫黄量，埥減杽曲線

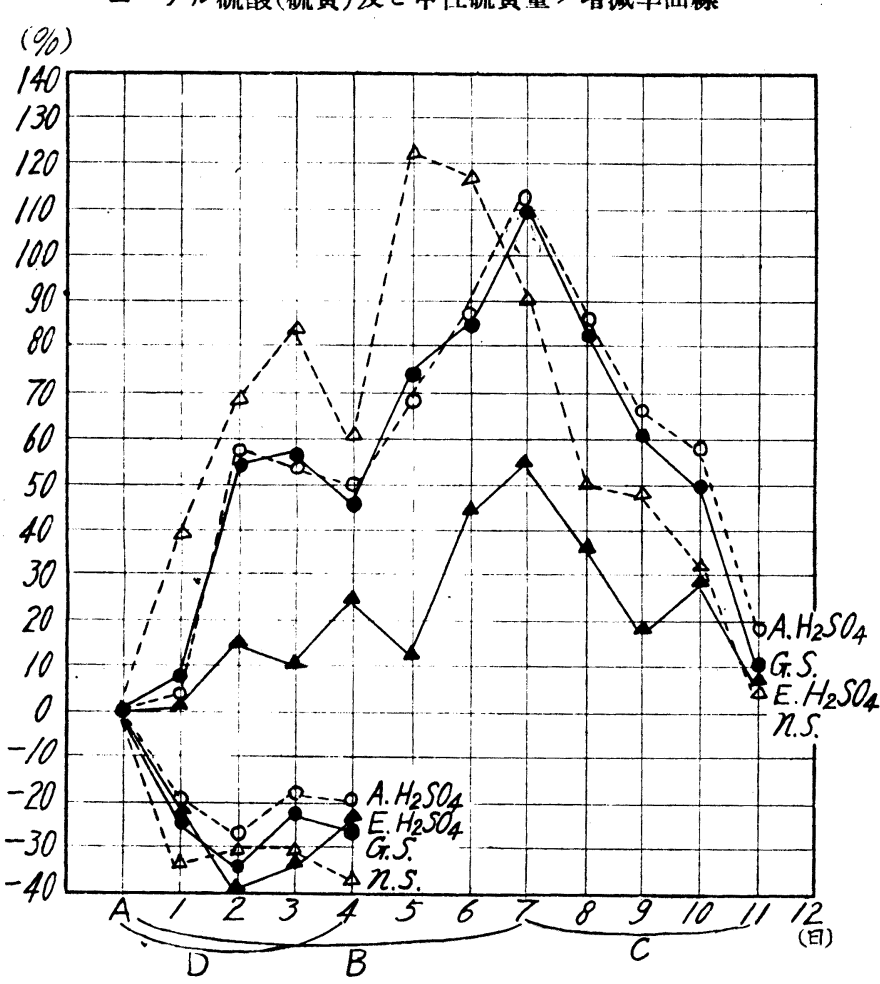

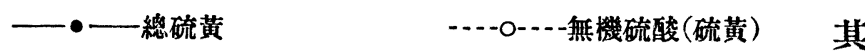

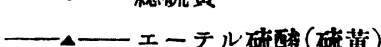

$\mathrm{A}=$ 前 期

$B=$ 試驗期 $(-)$

$\mathrm{D}=$ 試驗期(二)

硫

酸

殆

2

全

蚠

質

$\rightarrow$

體

队 於

㔔

永

解

亏

際

$\mathrm{C}=$ 後 期

中性硫黄 $\begin{array}{ll}\text { 尿 二 } & \text { N } \\ \text { 中 總 } & \text { ナ } \\ \text { 現 硫 } & \text { ๖。 }\end{array}$

原

著

二

N

其

队

存

在

二期歸ノ二末ノ近ト一中七学タ在

三三ル末未第似云定三う素ルハ

無於。日第二三人フセ含ル量モ硫

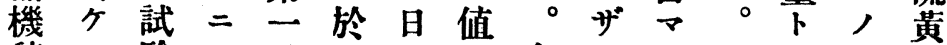

硫ル驗

酸 $\exists$ 期 略 $\exists$ 最り示人 モ

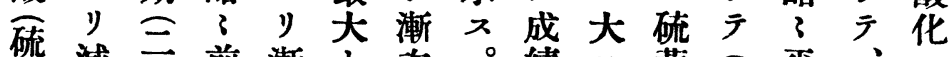

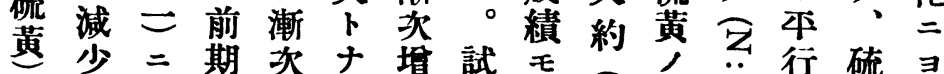

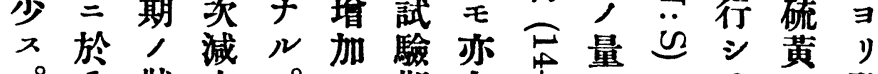

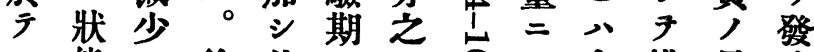

八態滛其三

前二其期广二=息》物泄量主
第
芼
吾
畐
亲
交 
第

五

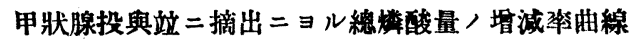

原

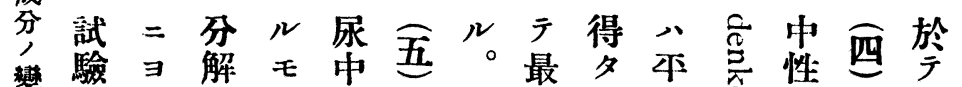

(\%)

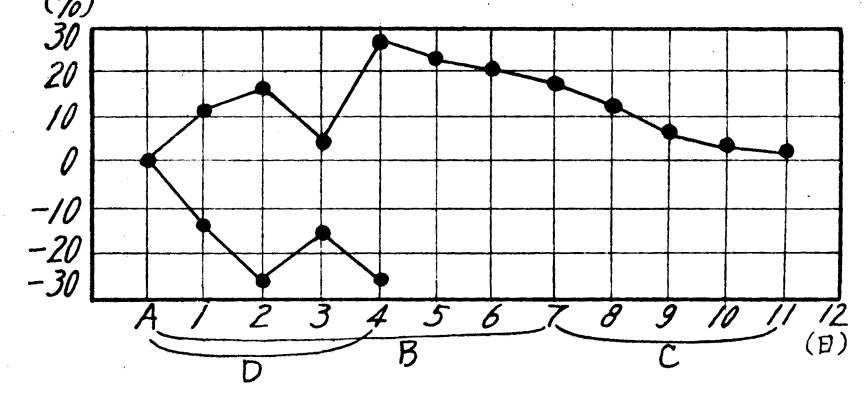

其 1 三 少 試

广 $工$ 期

末ル1ク

日硫 テ降二

二酸 $儿$ 下 後

於分硫 ス期

天量 酸 ○筑

最公不克

大腸硫試

1. 觉驗

$ナ=0$ 期

ル於

後 $ル$

期 蛋

二百

八梊

第 腐

一 敗

日,

多多

二三左 $ヨ$ ナ排燐驗卜。数等黄 性前少

就三右り

ノセテドス

第 ラ 發モ ル

三 驗七

一生、燐三爾期五

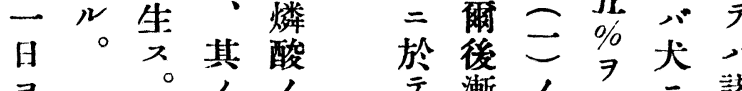

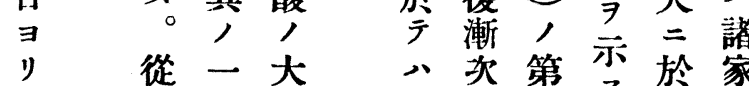

漸從二奆部前減第示於家

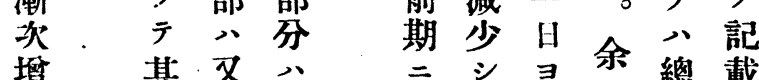

加 量千物 令期漸實硫致

第其

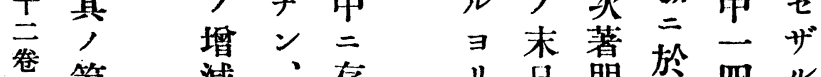

复第減、存早奛於四儿

二四 少核入著二三云朽飞

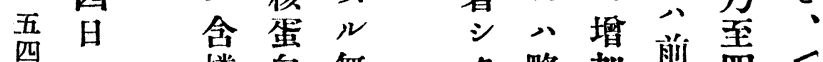

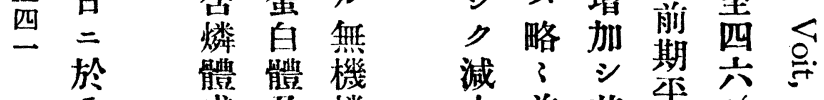

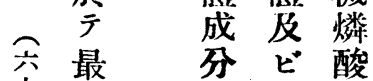

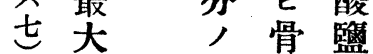

二 分 組 二

達 解 織 由

ス八等 來

度, ス
少前其年 $\%$

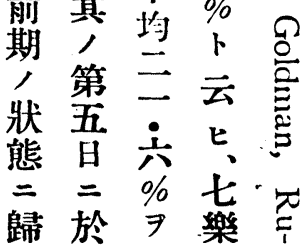

其 方

ルノ變

枺化

り日 $\Rightarrow$

滅二受

少小ク

ᄌ 略

3 試

前 驗

期 期

少 N

狀 二

態ノ

第

踩 -

ル曰

試 当

驗 徐

$\underline{\Xi}$

$=$

於

$\therefore$

モ

總

硫

$=$

略

乐

行

シ

增

加

站

=

減

少

百

期 今

$\stackrel{=}{=}$

三垻

$=$ 加
分

率

試

瞼

期

三

於 
第

六

圖

甲狀腺投與站二摘出ニヨル素、ナトリウム、

加里、石质及ビマグ子シウム量，㙁減率曲線

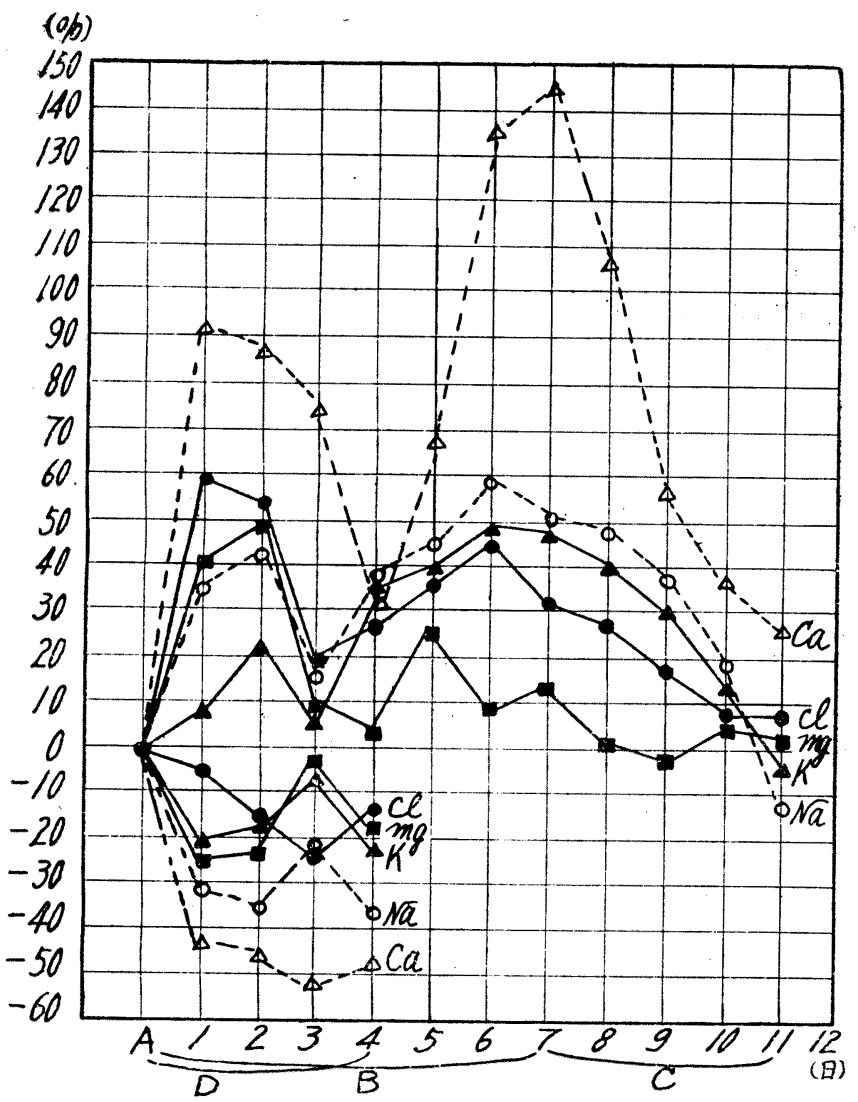

少り。試 亲其

後期 監 漸

期 三素 次

$=$ 三減 原

八人少

第 第 港

- - 後

日日期西

ヨ, 元

》y 末果

漸增旦 狀

次 加 $=$ 腺

減 シ

少始 前站

シ $x$ 期

其第, 出

, 宍 狀 $=$

末日 態寻

日 $=$ 二 尿

二於歸筬

八元分

略最維

了大試 炛

前卜驗 就

期ナ期 就

狀尗 三

態而 =

而於

歸 シ テ

ル ラ 》

試 其期

驗第 =

期 一 於

三 $\mathrm{r}$

三及第

二 ビ $\quad$ 卷

於第将

云減

八亘 少

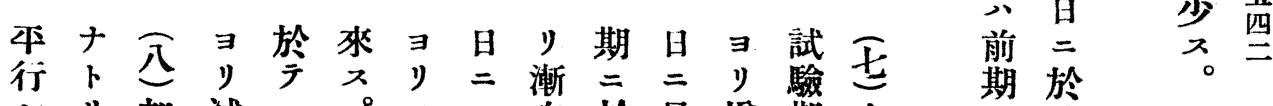

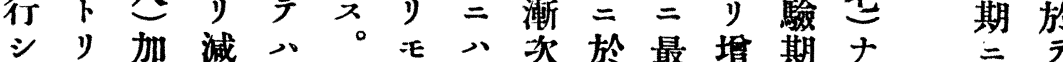

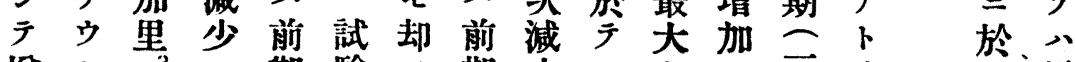

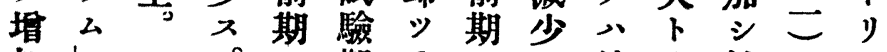

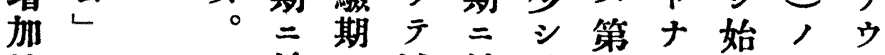

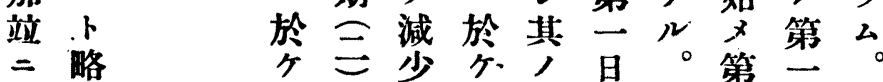

娍略 $\quad$ 少
增

儿 加

$\exists$ 著

リ 明

減 


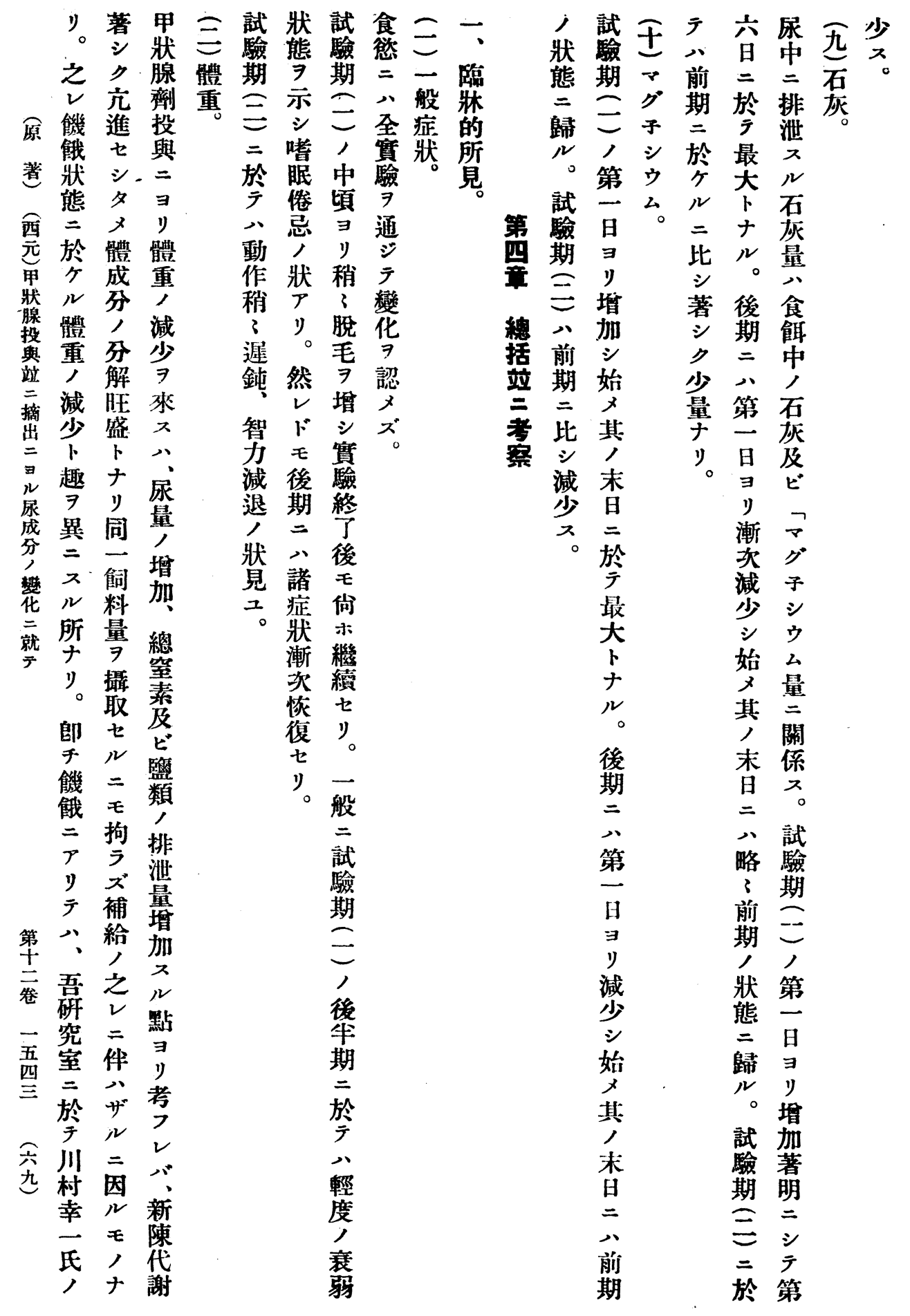




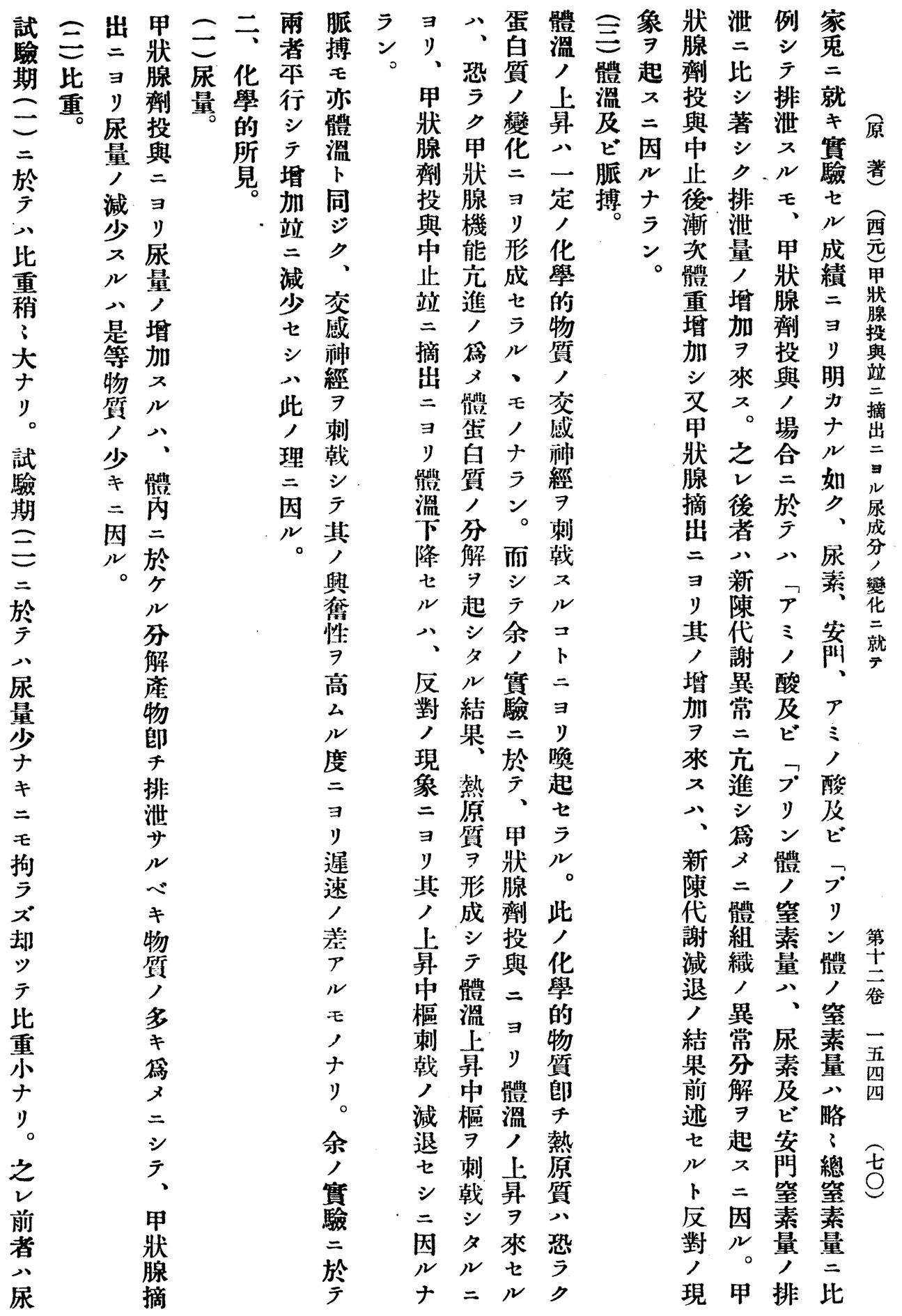




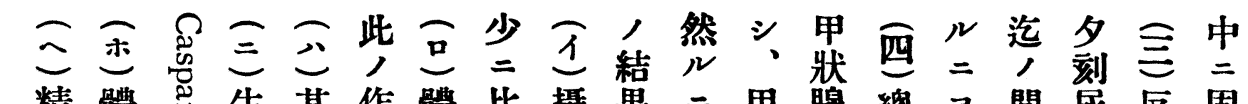

精體 导生其作體比攝果二甲腺總 $\exists$ 間尿反固

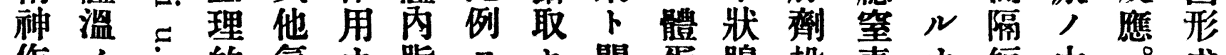

原作人。的氣子脂え七關蛋腺投素す短中。成

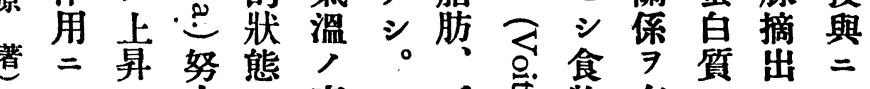

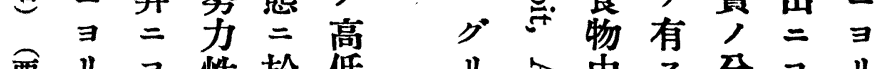

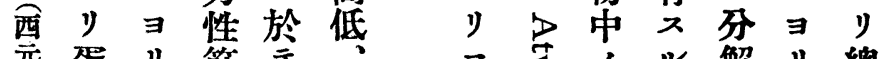

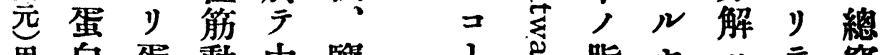

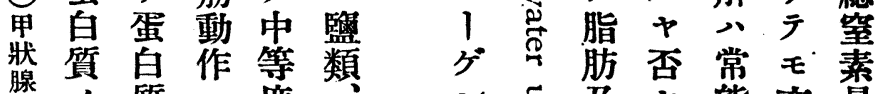

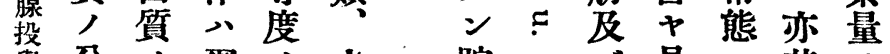

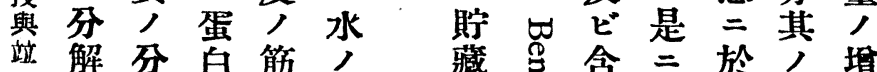

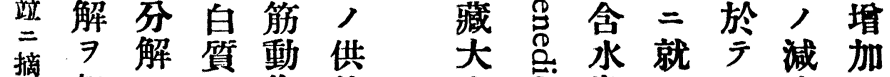

出起 $\Rightarrow$, 作給 $\quad$ 亭炭キモ少七

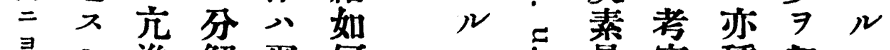

当進解蛋何我量察種起

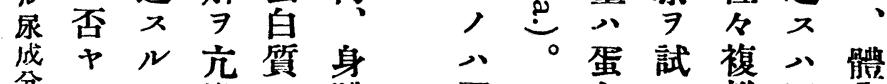

分二コ進, 體蛋白三雜明丙

變就卜ス泉質ンナカ蛋

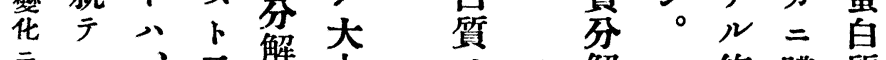

就六云解尔, 解條體啠

就末今年分件蛋分

名总乃范年解密二百解

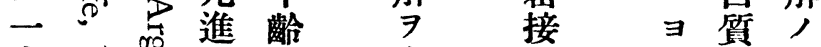

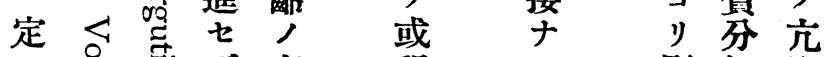

七富ザ老程激進

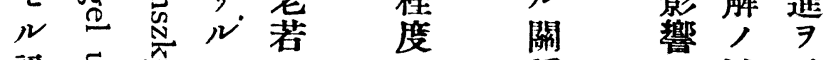

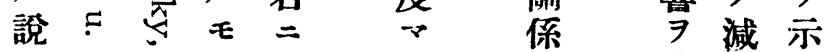

キ

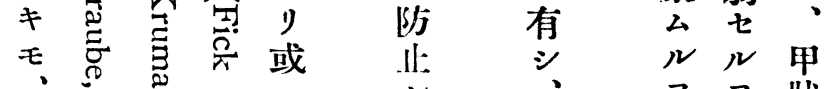

第高突导

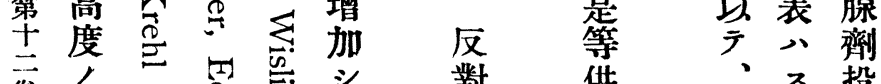

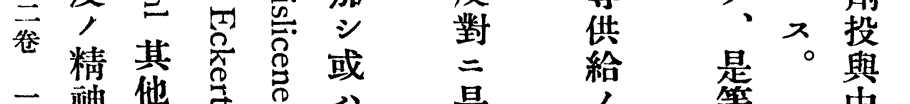

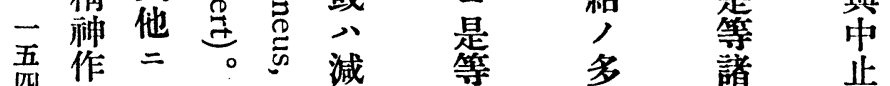

西角寻等多少諸步

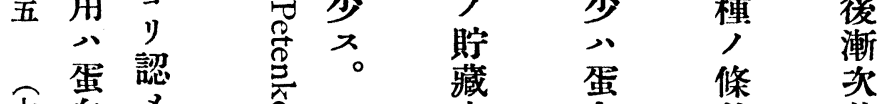

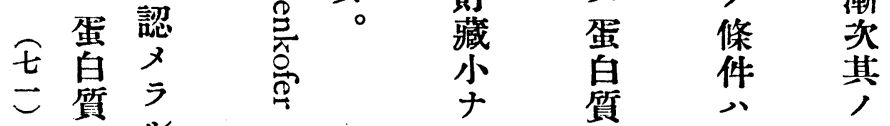

亏性 分

○篇又

×公伢此

消 $P$ 的

化少多

時力 量

$=リ=$

際性含

到有

胃呈新

丙视之

部 、 =

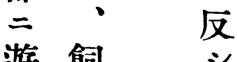

離料後

, 中者

監 =

酸比其

分較合

泌多量

シ量、少

之含 $\neq$

$\checkmark$ 水 $=$

炭 $\quad \exists$

相素

當令 ナ

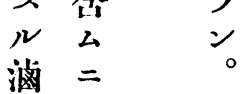

八 $\exists$

血”、

中灭

马 食

經 慨

于 攝

尿 取

中 後

二探

移尿

行 


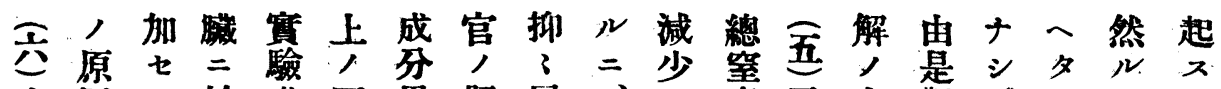

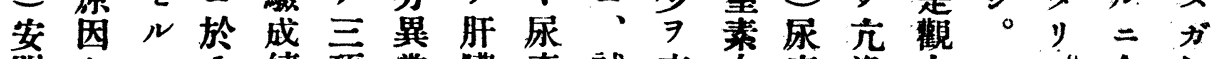

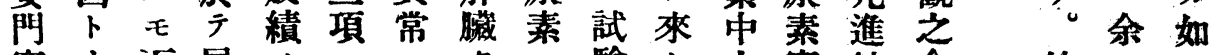
窒ナ寔尿

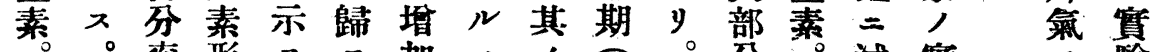

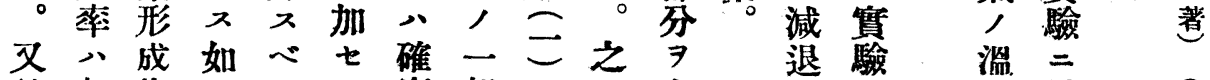
却却作クキシ實部

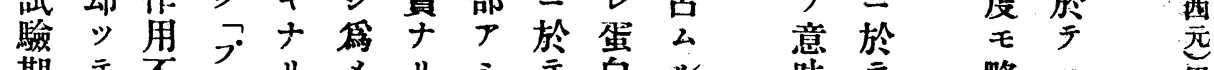
期テ不

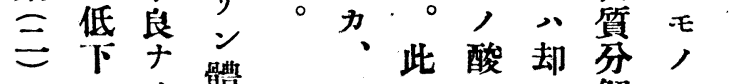

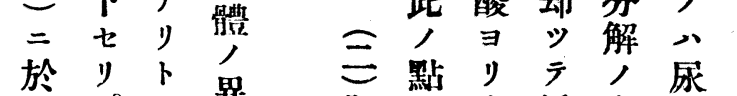

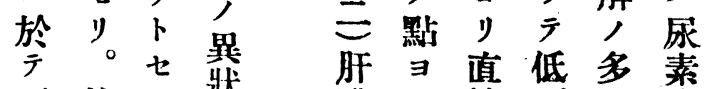

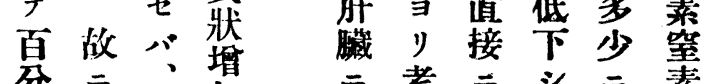

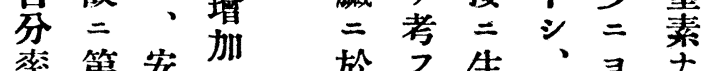

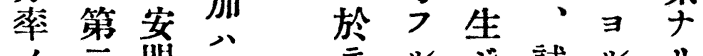

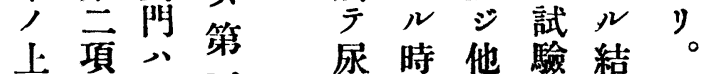

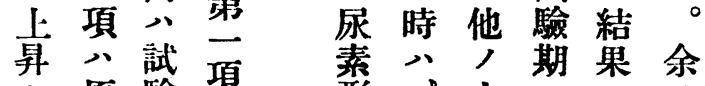

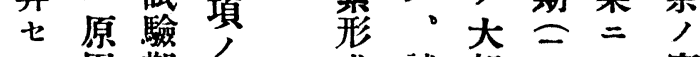
ル因期原成試部三シ 實 $\because 卜 三$ 原作驗分二テ 驗

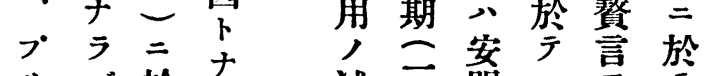

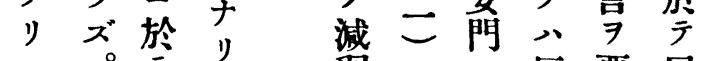
ン。少、躬二ヨ反要尿 體仍異 $七$ 於り對七素 及广常ミシ シ 移二ズ窒 ビ第增ミ 二百行上。素

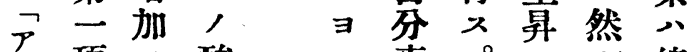
今項ス酸ル茶。スル總 ,及心方向而之窒 酸第年常

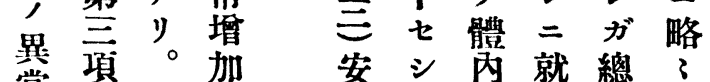
常項然 加安 減以第少、於考素行

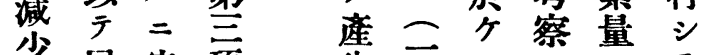

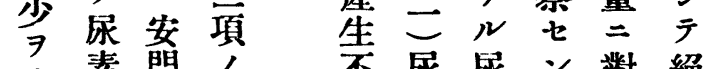

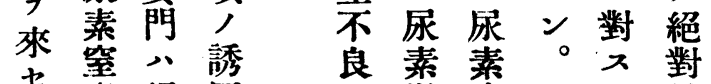

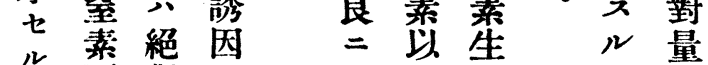

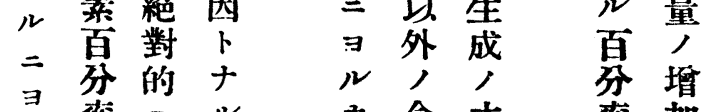
蔡 $=$ 力含主茶加 。低小窒要 7 站 下增肺以素器 見气 窒 素溫 定撗 量 二 增保食摘 加、堅 努 與 音 = 才八 椷 性 少筋 哇 勳 素

シ 作 尔

$\therefore$ \& 衡

明 精 保.

力神 y

$=$ 作 =

甲 用至

狀 $\quad \Rightarrow$ 严

腺ナテ

劑省 實

過 シ 歌

給 メ 7

站 ズ、開

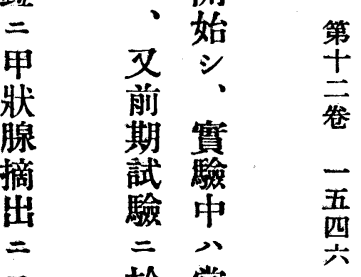

至於常

リ $\bar{~}$

體發同眇 蛋 七食

皇 シ

分 卜 與 


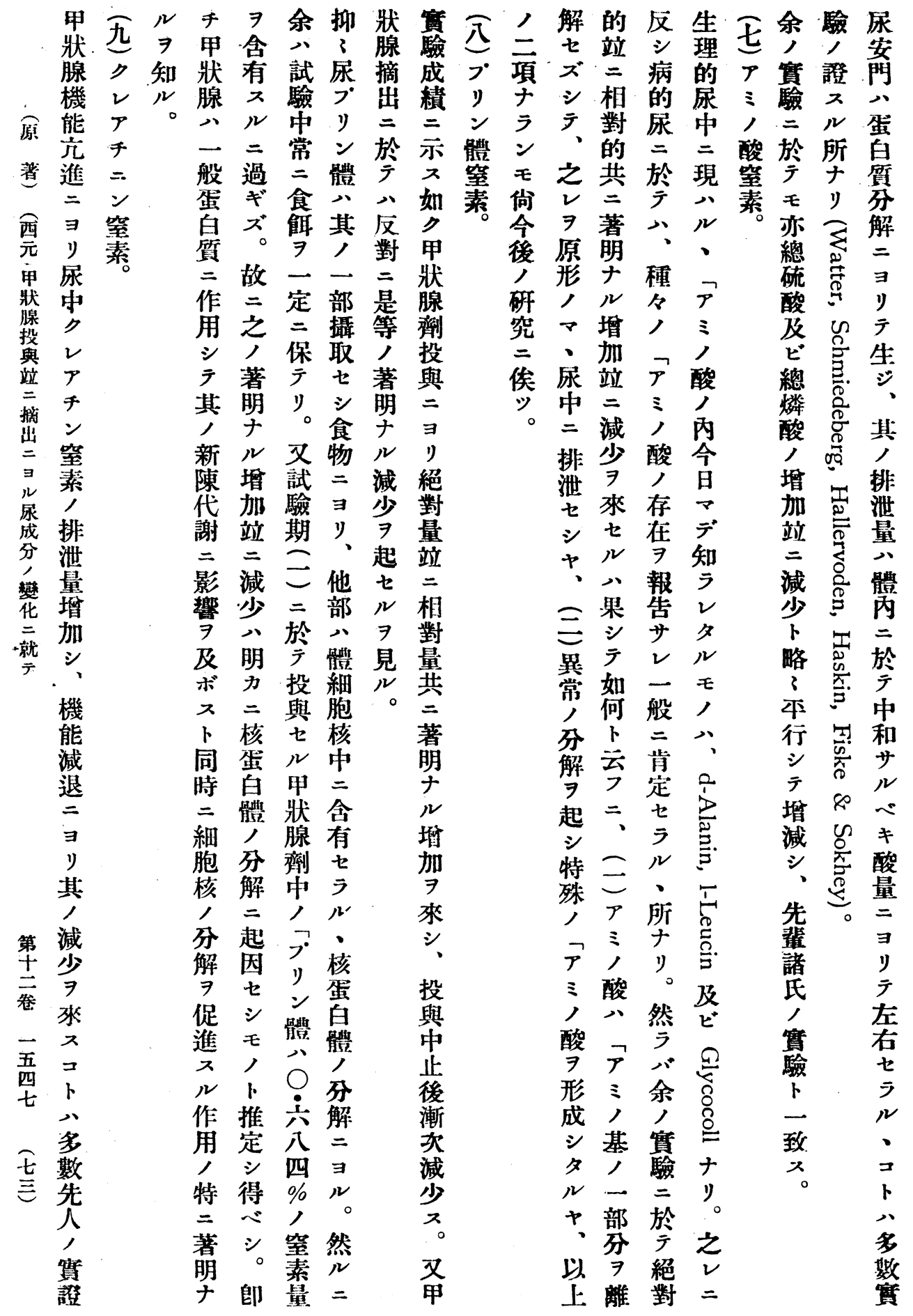




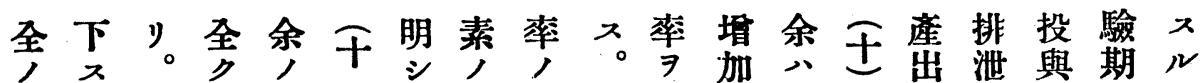

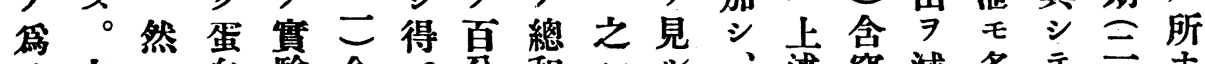

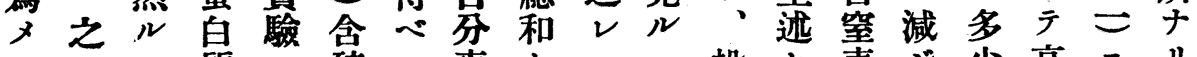

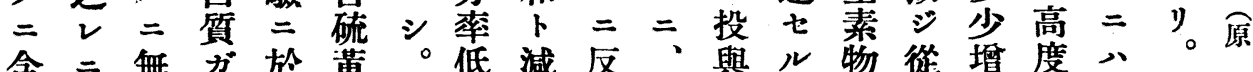

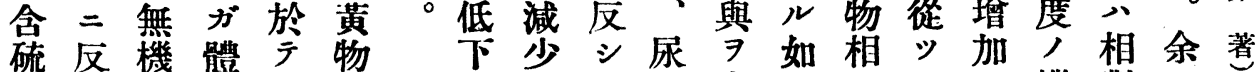

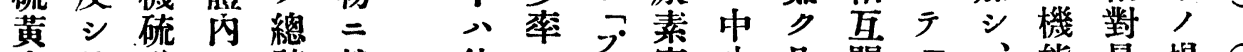

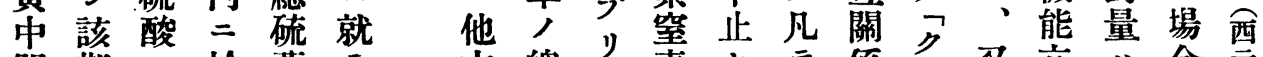

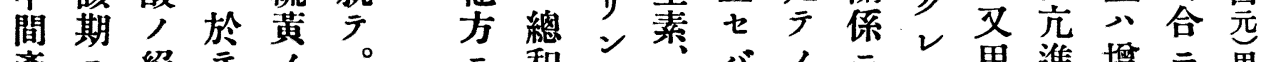
產二絕厂,

物 於 對 分 增

量解 加

生中八七 站 性總 $ラ=$ 夕硫硫減 橫黄 、少 二八量際八 因 絕 = 總 化對 略 發 窒

卜量?生素 見站本 做三行夕其 入 相 $シ$ V 心對テモト

キ量算, 略

モ共加 $=3$

, 三站米

ナ增 $=\bar{~}$ 行

》。妿減不。

而橥少少同之

テリ。關 ᄀ

此之百泉劣

酸之夏有广

化體率スル

機虫八ル硫

能白試 八酸

減買 驗 想以

退分期 像外

子解 入,

一站 こル含

層 $==$ 硫

確酸於難黄

實化示为物

于機少

ラ能 シ ザ殆

シ不クルン

么完低ナド

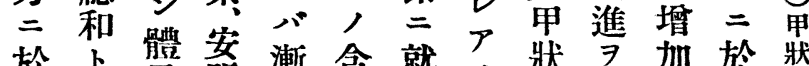
於卜體䢿漸含就手狀 $\exists$ 加於狀

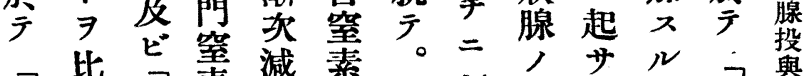

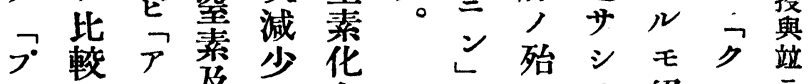

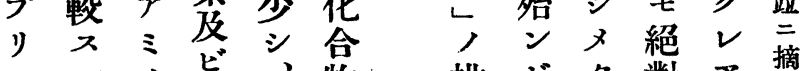
ンル, ビ、物、排 $ト$ 夕對 $\curlyvee$ 摘

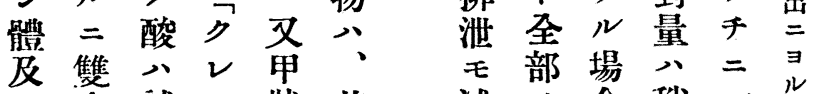
范試ア狀其減, 合稍ン存 $\neg$ 相驗 $千$ 腺, 少摘 $=3$ 窒盛 阝伯期二摘量石出八減素分 三仲三ン出三。組少心變

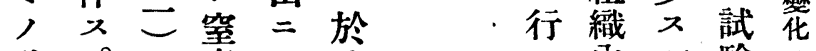

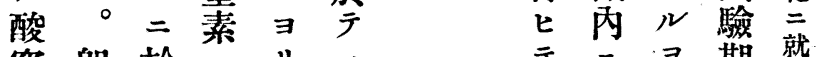
等即於少り ラ 素于今共減各 面方督試少多 㕣气 羷來少 率於試期入, 上衣驗云コ羑 算尿期こ十異 素 $=7 \mathrm{P}$ 恶三於實 2 少素云驗ド 補於低七正 得䢿厂下”。等 望低、然鸟 $\exists$ 素下試 以及 以羷二狀 广艺。期總腺 其 ᄀ然岂劑 共 然三素投 間 $v===$ 與 , $P$ 是於對 $=$ 消于等云 息 $=$ 八 准上百漸

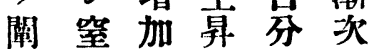

機於見三

能示元

隇

退々而

著于 $\mathcal{P}$ 對

竎余量

ラ, 實減

シ 產驗少

$x$ 出 $=x$

夕於儿等

場熷分モ。芼

合從如絕一

二ック對吾

:天、量元

、多采

ク量稍

レ先量志

$\mathcal{P}$ 甲增四

千 牀 加

ン $ン$ 腺

ノ, 贸 


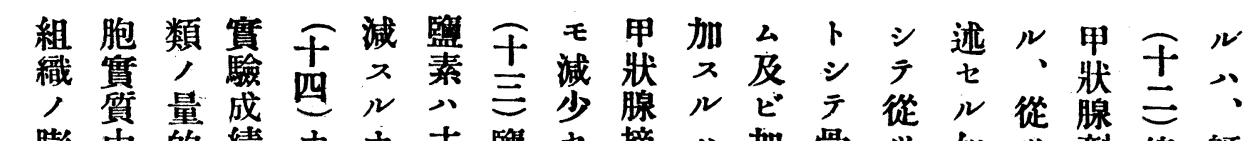

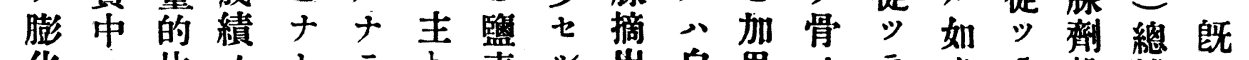

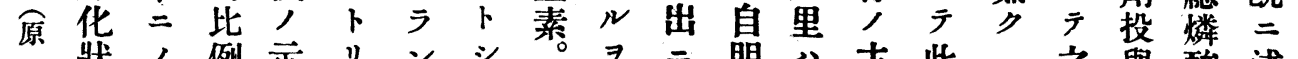
著態ミ如天

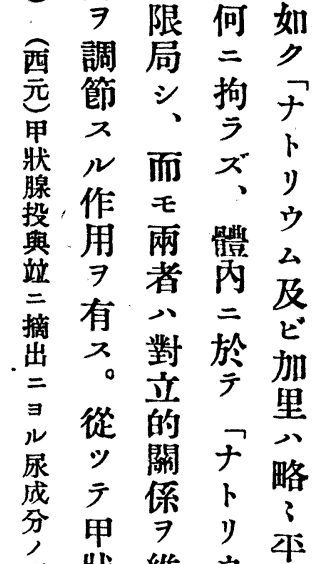
榃 狀 維 ウ尔 华腺 持公 行 就機 ル 機 ル 主增 熊, 主品 常 = シ 站 = シ テ 減 ヨテ、血減 是體及尔 等 內 ビ 物留織見 第人增五夜 芼加 互 中 由 泣洷 存 食

$\overrightarrow{\overrightarrow{1}}=$ 透 在 物.

吾減壓兰、

九少公 加

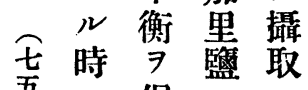
吾二保心具 於于、殆 ル モ且ト種 亦 $ッ$ 細留 ナ、文理レ分中りガ

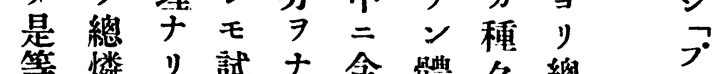
リ 等 燐り。試 ナ 含 體 な 總

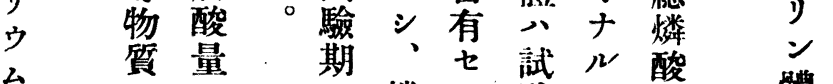
么 質量 期燐亏驗階量㣂 卜伴娍二酸儿期級, 代 結 $七$ 少 = 加、三

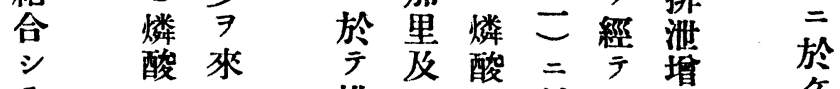
テ ノ 酸排 ビ テ尿排 中 泄之量酸排著り 本尿

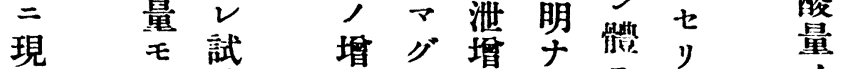

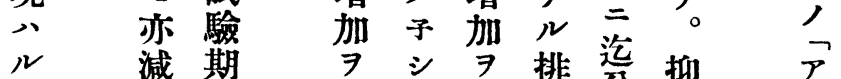
、減期 來 ウ來渄扮抑劣

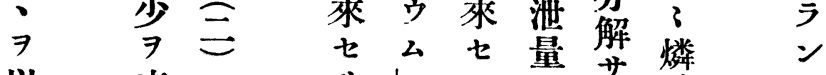

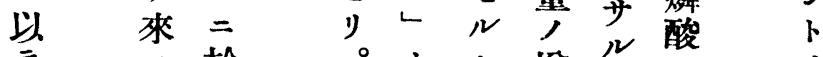

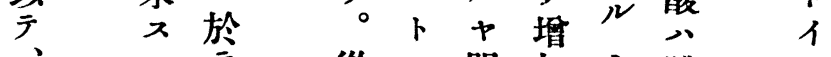
+ 二テ 從 シ 明加、體計 ナ 因 フ产テカ

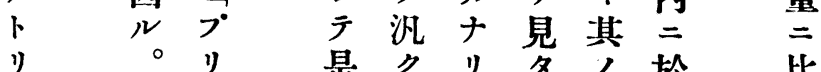
ウ 等 組。少中方等

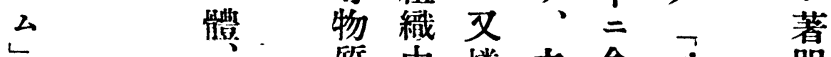
石孟中燐之念 $7^{\circ}$ 明 排灰共存八核セン增

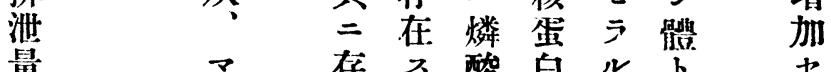

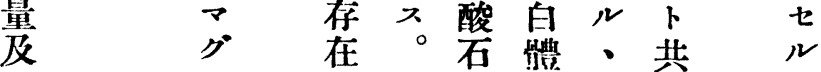
ビ 子 子而灰, 燐三 录 $シ$ 兵分酸核以 量 ウ 燐 テ ビ解モ蛋兵 二 么 酸石燐七亦白十 略父灰酸分體り。 本加泄 $\checkmark$ グ基七 行里量グ子クラ含

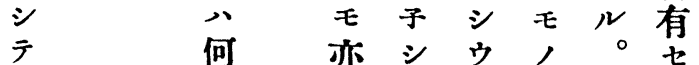
增增ウ $レ$ 前 


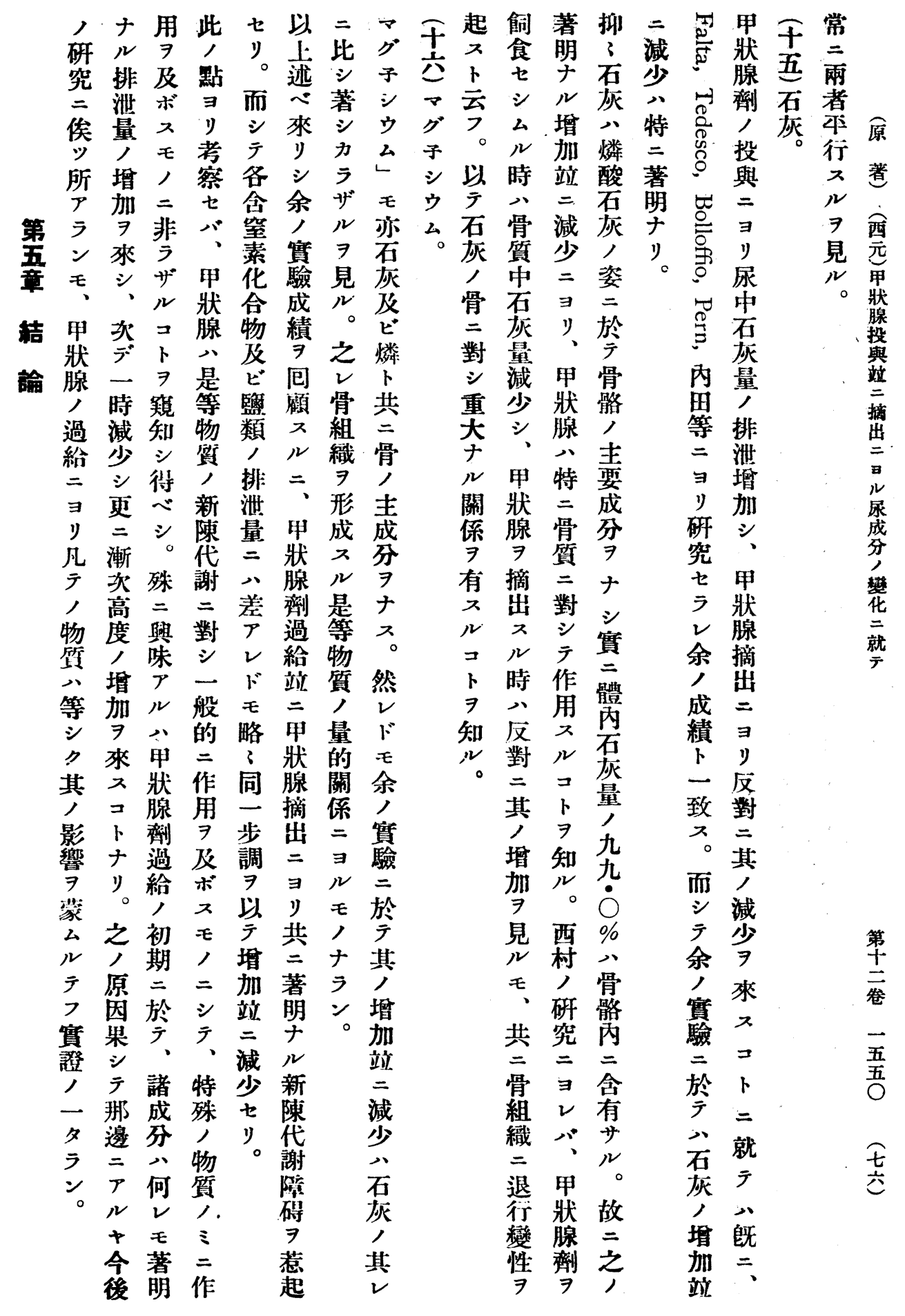




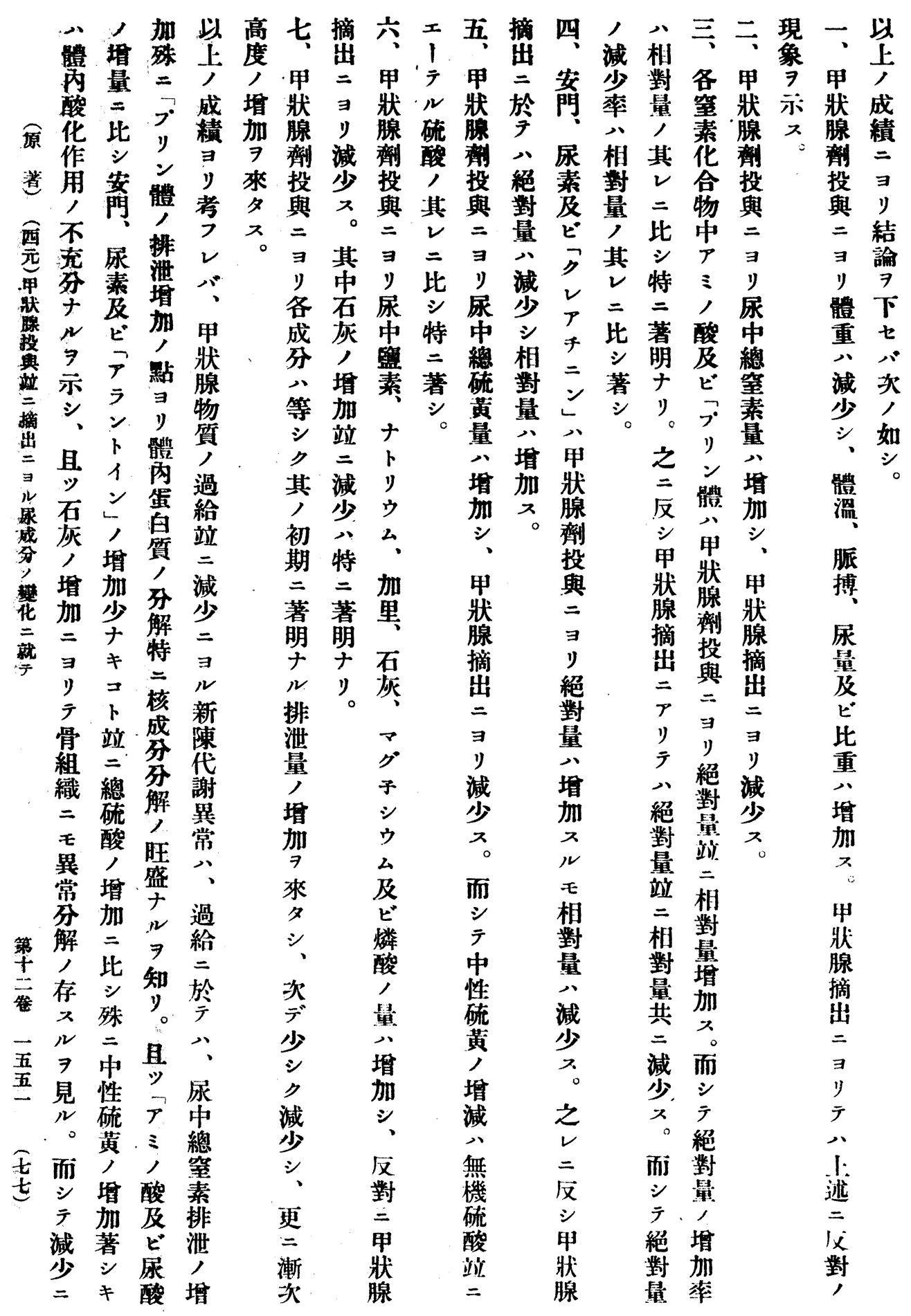




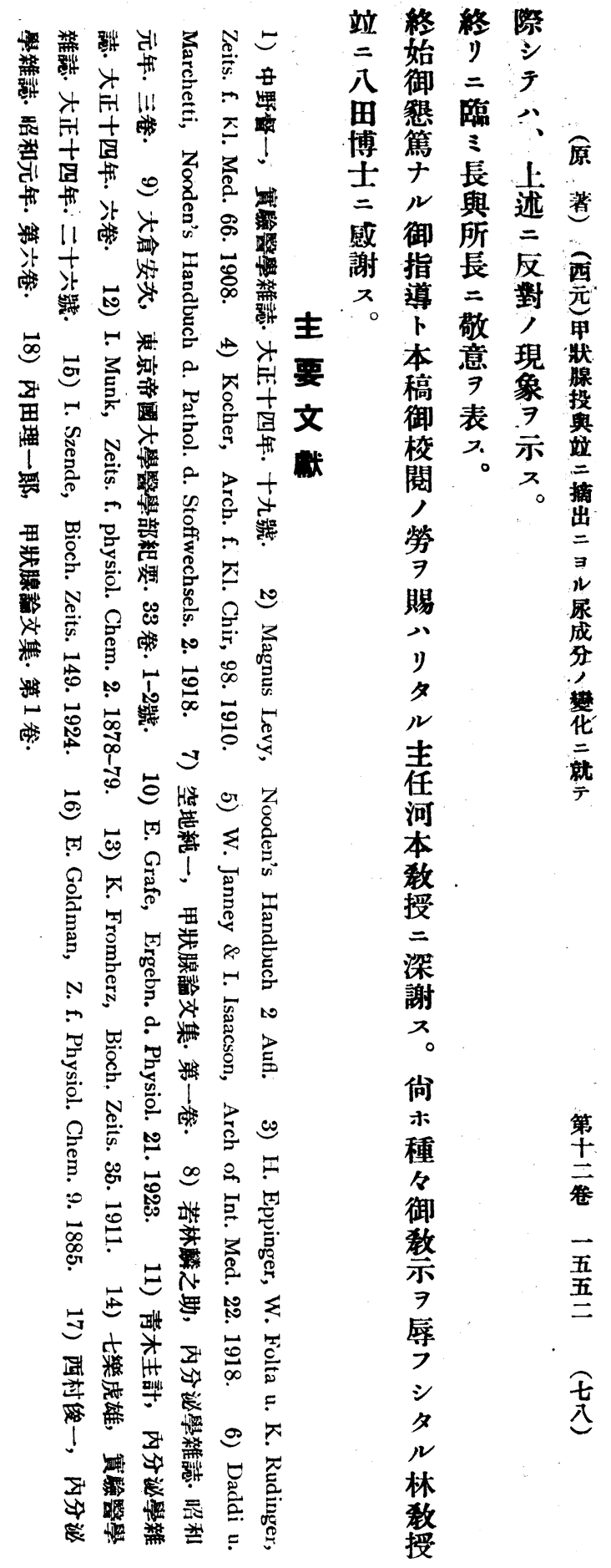

